\title{
Flabellum: Ulises, la Catedral de Santiago y la Historia del Arte medieval español como proyecto intelectual
}

\author{
Francisco PRADO-VILAR \\ Universidad Complutense de Madrid
}

\begin{abstract}
Il aimait à se retirer, dans le travail et la méditation, loin des bruits du monde: il disparut dans la bourrasque: la mer le prit, la brume l'ensevelit; comme les héros des légendes celtiques, il n'est pas revenu ${ }^{1}$.
\end{abstract}

M. Aubert, "A. Kingsley Porter (1883-1933)"

Delineada sobre la superficie de una vieja fotografía distinguimos la figura de Arthur Kingsley Porter, dirigiéndose con paso decidido hacia una barca que le espera en ese brumoso mar de las costas de Irlanda en el que habría de perderse sin

1 M. Aubert, “A. Kingsley Porter (1883-1933)”, Revue archéologique, 6ème série, vol. 2 (1933), pp. 326-28, esp. p. 328. Este artículo se integra en el proyecto de investigación que dirijo: "Arte medieval español y cultura europea: Trasfondo clásico e impacto en los discursos de la modernidad" (HA2010-20357), financiado por el Ministerio de Ciencia e Innovación. Agradezco a los otros investigadores de este proyecto, Herbert L. Kessler de la Universidad Johns Hopkins, Leonard Barkan de la Universidad de Princeton y Jas Elsner de la Universidad de Oxford, quienes son a la vez mentores, amigos y compañeros intelectuales, su participación. Quiero hacer también una mención especial a la memoria de Leo Steinberg, recientemente fallecido, cuyas Charles Eliot Norton Lectures pronunciadas en la Universidad de Harvard en 1996 supusieron un hito crucial en mi formación como historiador del arte. En el núcleo de mi concepción de la historia del arte como proyecto intelectual se encuentran dos de sus ensayos: "Objectivity and the Shrinking Self," en Other Criteria: Confrontations with Twentieth-Century Art, Londres, Oxford University Press, 1972, pp. 307-21; y el texto de la conferencia que pronunció en el congreso de la Asociación de Historiadores del Arte de América (College Art Association), Filadelfia, 21 de Febrero de 2002, publicado con el título de "False Starts: Loose Ends", The Brooklyn Rail (Junio 2006), http://brooklynrail.org/2006/06/art/leo. Su carrera nos brinda un ejemplo de fortaleza intelectual y compromiso ético, habiéndose resistido con determinación a lo largo de su vida a arrastrar sus argumentos al terreno del craso positivismo en el que se movían la mayoría de sus detractores. A cada reducción simplista de sus ideas por parte de éstos, Steinberg respondía tejiendo velos de pensamiento cada vez más finos, exponiéndose a los zarpazos de la crítica fácil, pero dejándonos como resultado un lienzo de seda traslúcido a través del que podemos vislumbrar los contornos de ese monumento resplandeciente que es la Historia del Arte como proyecto intelectual. Mientras que hoy las victorias coyunturales de sus críticos languidecen en los baúles a los que el tiempo relega de forma inexorable los productos más prosaicos del intelecto humano, cada uno de sus libros y ensayos florecen palpitantes de vida en manos de nuevos lectores que descubren en ellos una voz que les recuerda lo que la Historia del Arte y ellos mismos pueden llegar a ser. 
dejar huella el 8 de julio de 1933 (fig. 1)². Dos días más tarde, el New York Times se hacía eco de la noticia indicando que una borrasca había volcado la embarcación en la que se dirigía a Inishbofin, donde se tomó esta fotografía - una pequeña isla célebre por haber sido elegida por San Colman en el s. VIII para fundar una comunidad monástica y donde Porter había construido una sencilla casa de pescadores en la que retirarse a trabajar y meditar loin des bruits du monde. A su muerte, Porter dejó inacabado un estudio sobre una tosca escultura irlandesa en el que exploraba un tema que le había interesado de forma recurrente: la pervivencia del imaginario pagano en el arte cristiano medieval. El borrador de este ensayo, publicado póstumamente en el Burlington Magazine, nos ofrece la instantánea de una mente animada hasta el final por una curiosidad casi juvenil, y concluye con un pensamiento que, a la luz de su inesperada desaparición, resulta conmovedor: "Estas y otras mil preguntas afloran en mi mente y mis labios. En un día no muy lejano, quizá sea posible encontrar respuestas"3.

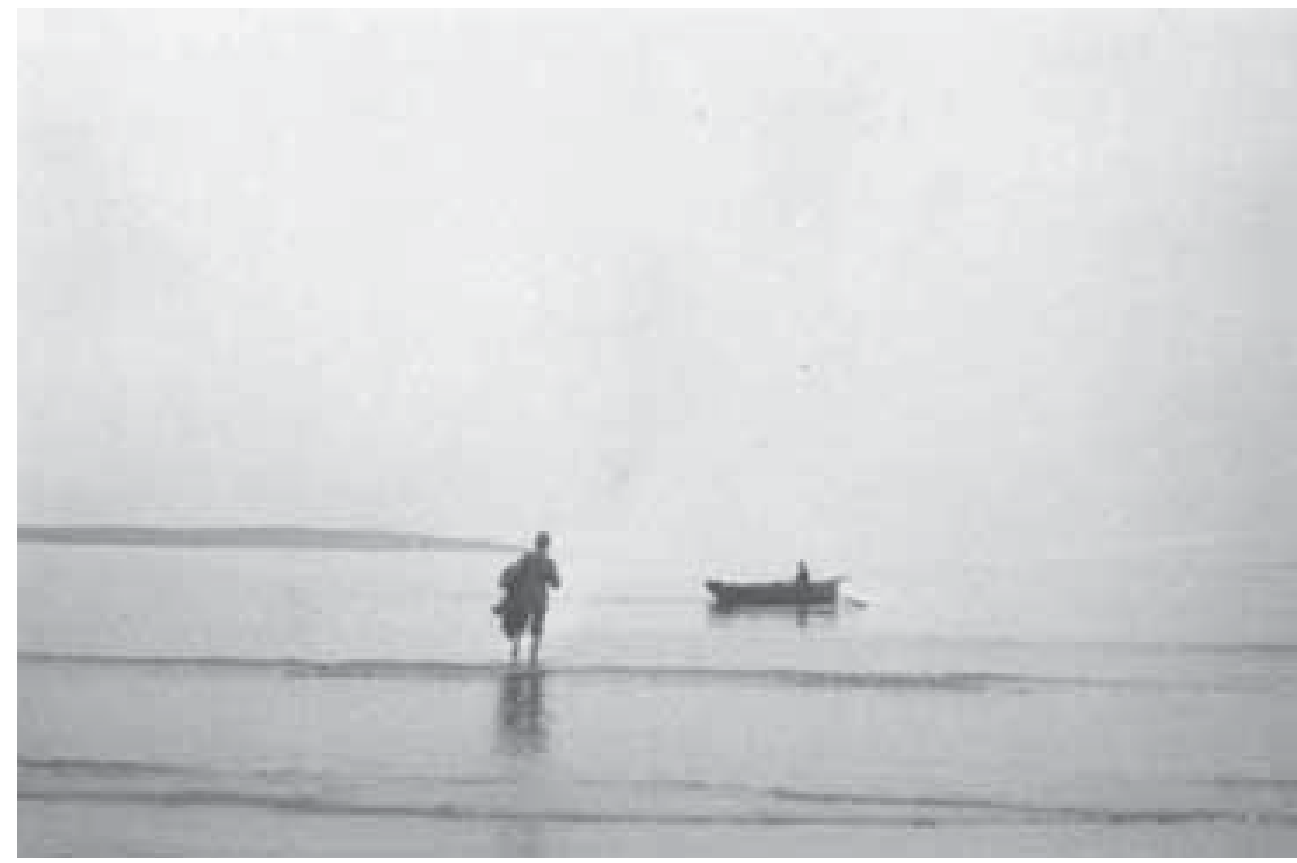

Fig. 1. A. K. Porter en la isla de Inishbofin. Harvard University Archives, Arthur Kingsley Porter Papers (HUG 1706.125 (box 1, ff3, \#12)).

2 Arthur Kingsley Porter Papers (HUG 1706.125 (box 1, ff3, \#12)). Agradezco al magnífico equipo humano de los Harvard University Archives por su asistencia en la localización de esta foto. p. 228 .

A. K. Porter, "A Sculpture at Tandragee", The Burlington Magazine, 65.380 (1934), pp. 227-30, esp. 
En la antigua fotografía vemos a Porter ante la inmensidad del océano Atlántico en el que se perdió y donde su biografía entró en la dimensión del mito. Como observó Marcel Aubert en su elocuente obituario, su misteriosa muerte recordaba a la de los héroes de las leyendas medievales, poniendo así un lírico colofón a una vida marcada, como la de aquellos, por el viaje y la aventura, por un sentido incansable de la búsqueda personal, intelectual y espiritual ${ }^{4}$. Esa búsqueda se había desarrollado principalmente por los caminos de la peregrinación a Santiago de Compostela, que Porter había recorrido con una cámara documentando fotográficamente los monumentos que estudiaba. El resultado fue una magna obra, Romanesque Sculpture of the Pilgrimage Roads (1923), que, integrada por nueve volúmenes de fotografías y sólo uno de texto, constituye un diario en imágenes de sus viajes ${ }^{5}$.

La ruta trazada por Porter con su cámara la transitó un joven llamado Meyer Schapiro, primero a través de la senda de fotos metódicamente clasificadas en el archivo privado del profesor de Harvard en su casa de Cambridge, y luego en su primer viaje de investigación a Europa en 1926 donde utilizó el lápiz de forma similar a la que Porter había empleado el objetivo para hacer inteligibles sobre el papel sus observaciones ${ }^{6}$. Cuando años más tarde Schapiro, ya consagrado como historiador del arte, retornó a Cambridge para pronunciar las Charles Eliot Norton Lectures de 1967, dedicadas a la escultura románica, reservó su primera mención para el pionero profesor:

Cuando era estudiante de doctorado... tuve la fortuna de acudir como invitado a su casa, donde me dio acceso a su inmensa colección de fotografías, en la que pasé muchas horas, incluso días enteros... Y no hay ningún problema sobre el que trate hoy, de hecho, no he tratado sobre ningún problema en estos años, en el que no me haya referido a su trabajo o haya encontrado en algunas partes del mismo un estímulo, una idea nueva, una conjetura sorprendente, o algún documento que, de otra forma, no hubiese podido hallar?

4 Para una apreciación de la vida y obra de Porter: L. Seidel, "Arthur Kingsley Porter: Life, Legend, and Legacy", en The Early Years of Art History in the United States. Notes and Essays on Departments, Teaching, and Scholars, (C. H. Smyth y P. M. Lukehart, eds.), Princeton, Princeton University Press, 1994, pp. 97-110.

5 A. K. Porter, Romanesque Sculpture of the Pilgrimage Roads, 10 vols., Boston, Marshall Jones Company, 1923. Para un análisis de las implicaciones de esta obra y la figura de Porter en la caracterización del románico como un "arte de desplazamientos", véase F. PRADO-VILAR, «Diario de un argonauta: En busca de la belleza olvidada», Anales de Historia del Arte, Volumen Extraordinario (2010), pp. 75-107. Véase también J. MANN, "Romantic Identity, Nationalism and the Understanding of the Advent of Romanesque Art in Christian Spain”, Gesta 36.2 (1997), pp. 156-64; e ID., "Georgiana Goddard King and A. Kingsley Porter Discover the Art of Medieval Spain", Spain in America: The Origins of Hispanism in the United States, (R. L. KAGAN, ed.), Chicago, University of Illinois Press, 2002, pp. 171-92.

6 Una parte de los cuadernos de Schapiro, correspondientes a su viaje de investigación a Europa y el Próximo Oriente en 1926-27, ha sido publicada en Meyer Schapiro Abroad: Letters to Lillian and Travel Notebooks, (D. Esterman, ed.), Los Angeles, The Getty Research Institute, 2009.

7 M. Schapiro, Romanesque Architectural Sculpture. The Charles Eliot Norton Lectures, (L SEIDEL, ed.), Chicago, The University of Chicago Press, 2006, pp. 3-4. Para un excelente análisis de la relación entre Porter y Schapiro, véase la introducción de L. Seidel, pp. XI-L; también la magnífica reflexión de T. Crow, La inteligencia del arte, Méjico, Fondo de Cultura Económica, 2008, pp. 15-80. 
Recientemente publicadas con una extraordinaria introducción de Linda Seidel, las Norton Lectures de Schapiro son, en cuanto a su génesis y la problemática de su concepción, un documento clave para la historiografía del siglo XX, pero a la vez descorazonador en su realización final y contenido intelectual. Schapiro las contempló como una oportunidad para publicar, a sus 63 años, el estudio general definitivo sobre la escultura románica. En él se plasmarían las ideas maduradas durante tres décadas de docencia en la Universidad de Columbia, reflejando la evolución que había experimentado su pensamiento desde sus artículos seminales de los años $30^{8}$. Sin embargo, el texto final carece de la incisiva frescura metodológica de esos primeros estudios y sus análisis tienden a perderse en una sucesión de ejemplos que le impiden profundizar en cuestiones importantes. Dado que las conferencias estaban en parte concebidas como un homenaje a la figura y la obra de Porter, con el que había planeado una colaboración que nunca llegó a realizarse, resulta más sorprendente todavía la práctica total ausencia del arte románico español en sus discusiones, hasta tal punto que incluso se diría que Schapiro hizo un ejercicio deliberado de circunvalación de una España que en esos momentos, a diferencia de la época en la que él la había visitado en su juventud, estaba bajo el yugo franquista que sin duda aborrecía. Leyendo las Norton Lectures como un intento por parte de Schapiro de retomar una conversación truncada con Porter, se pueden sentir los vacíos intelectuales dejados por la desaparición de éste -vacíos de naturaleza conceptual y temática que hubiesen sido menos evidentes si Schapiro hubiese contado todavía con la presencia de su erudito interlocutor.

Los diferentes niveles de análisis de este ensayo establecen una conversación con varias voces y objetos que encontramos al borde del abismo del olvido. Se trata, en cierta medida, de una reflexión abierta, en el sentido del loose end de Steinberg, sobre uno de los aspectos más intangibles a los que me he enfrentado en mis estudios recientes sobre el arte románico: la fragilidad del registro arqueológico y de las voces, tanto históricas como contemporáneas, que son más relevantes para su entendimiento. Éstas conforman un corpus de pensamiento que por su propia singularidad y delicadeza ha sido más vulnerable a ser esquilmado por las garras del tiempo o a verse acallado bajo la uniformidad monorítmica de discursos más prosaicos. La fotografía tomada en la playa de Inishbofin constituye un apropiado epílogo para el diario en imágenes de la carrera de Porter y un sugerente prólogo para esta meditación sobre la fragilidad de la historia del arte medieval español como proyecto intelectual. Pocas veces un registro fotográfico captura de forma tan esencial el sentido de una vida, tanto por su materialidad física, como testimonio de la trayectoria intelectual de un hombre que incansablemente documentaba a través de ese medio sus objetos de es-

8 Sobre las aportaciones de los artículos de Schapiro en los años 30, véase M. CAmille, "How New York Stole the Idea of Romanesque Art," Oxford Art Journal 17 (1994), pp. 65-75. Para una revisión crítica de la valoración que hace Camille de esos trabajos de Schapiro, véase F. PrADo-VILAR, "Tragedy's Forgoten Beauty: The Medieval Return of Orestes", en Life, Death and Representation. Some New Work on Roman Sarcophagi, (J. Elsner y J. Huskinson, eds.), Berlín y Nueva York, Walter de Gruyter, 2011, pp. 83-118, esp. pp. 109-14. 
tudio, como en el poder evocador de la imagen que registra, donde la figura solitaria de Porter parece perderse entre la niebla de ese océano que le sirvió de pantalla de pensamiento para dar respuesta a las preguntas que le apasionaban.

\section{Odysseus christianus: de la nube del olvido a la columna de mármol}

Encontraron en la playa una nave que les había sido preparada por Dios, en la cual se hicieron a la mar llenos de gozo dando gracias a Dios de manera unánime tras embarcar el sacratísimo cuerpo, y después de evitar Escila y Caribdis junto a las peligrosas Sirtes, siguiendo el rumbo de la mano del Señor, arribaron a bordo del afortunado navío... al puerto de Iria9 .

Fue a orillas de ese océano en el que Porter se perdió donde, ochocientos años antes, otro intelectual con el nombre de Giraldo de Beauvais trabajaba en una obra en la que intentaba preservar la memoria del mismo paisaje humano y monumental al que el profesor de Harvard dedicó gran parte de su vida. Escribía Giraldo para que el mundo que conocía y la hazañas de su patrón, el arzobispo de Santiago Diego Gelmírez, no se viesen envueltos en la "nube del olvido" (oblivionis nube) ${ }^{10}$. De los diversos autores que participaron en la composición de la hoy llamada Historia Compostelana, Giraldo es el más culto, inteligente, perceptivo y poético. Mientras que Nuño Alfonso, el iniciador de la obra, se mueve, no sin cierta destreza, en el prosaicismo de la trascripción documental, Giraldo eleva su mirada, y utiliza la ductilidad y riqueza metafórica de su prosa para dejarnos el registro más vivo, más memorable y más valioso de las circunstancias históricas de las que fue testigo ${ }^{11}$.

Lo encontramos al lado de Gelmírez en el Monte del Gozo, emocionándose al aproximarse a Compostela portando la reliquia de la cabeza de Santiago ${ }^{12} \mathrm{o}$ atemo-

9 E. FAlque Rey, trad., Historia Compostelana, Madrid, Akal, 1994, pp. 67-68. A partir de aquí citado como Historia Compostelana.

${ }^{10}$ Giraldo usa esta expresión, entre otras ocasiones, en el prólogo del libro II, véase Historia Compostelana, p. 295.

11 Para los diferentes autores de esta obra, véase Historia Compostelana, pp. 7-31; y F. LóPEz AlsinA, La Ciudad de Santiago de Compostela en la Alta Edad Media, Santiago de Compostela, Ayuntamiento de Santiago de Compostela, 1988, pp. 46-93. La Historia Compostelana es un texto de gran relevancia para explorar cuestiones importantes que han ocupado a la crítica de la literatura medieval en los últimos años, en torno a las conexiones entre el lenguaje, el espacio, el cuerpo y la subjetividad. Para un interesante estudio en esta línea del De Administratione del abad Sugerio de Saint Denis, contemporáneo de Gelmírez, véase S. Spence, "Writing out the body: Abbot Suger, De Administratione", Texts and the Self in the Twelfth Century, Cambridge, Cambridge University Press, 1996, pp. 19-54.

12 Véase Historia Compostelana, p. 268: “Después que el obispo llegó al monte del Gozo... le salieron al encuentro el clero y el pueblo de toda la ciudad venerando con suma alegría el precioso tesoro. Y el propio obispo, descalzo y cantando salmos junto a los canónigos entró en Compostela. ¡Oh, cuánta alegría la del clero y el pueblo! Yo mismo al regresar con el obispo rompí en llanto por el inmenso gozo". 
rizado al recordar la misión que le habría de ser confiada dos años más tarde, en 1118, cuando fue enviado a Roma ante el papa Calixto II con el fin de solicitar la dignidad arzobispal para la sede compostelana:

Cuando recuerdo cuántos esfuerzos sufrió mi cuerpo y tanta ansiedad mi espíritu en esta huida de Caribdis, vive el Señor y vive mi alma que dentro de mi me estremezco todo $\mathrm{y}$ al estremecerme me horrorizo. No voy a recorrer con la pluma lo que mi mente a penas se atreve a traer a la memoria por tantos esfuerzos y ansiedades ${ }^{13}$.

Esta es una de las cinco ocasiones en las que Giraldo invoca a personajes de la Odisea para describir los peligros que acechan a los viajeros compostelanos en su periplo por tierras hostiles. Menciona de nuevo a Caribdis, uno de los monstruos marinos que, junto con Escila, acosan a Ulises en la épica homérica a su paso por el estrecho de Mesina, al referirse a los difíciles escollos que tiene que sortear Gelmírez en sus desplazamientos fuera de su sede, especialmente a través de los caminos de Aragón (territorio al que Giraldo denomina frecuentemente Caribdis):

Luego, tras recibir su consejo, se marchó alegre aunque todavía receloso y, como una paloma escapada de las uñas del gavilán con rapidísimo pero temerosísimo vuelo surca los aires, así el obispo pasó por el reino del tirano aragonés, o mejor aún, por medio de Caribdis, con paso rápido ${ }^{14}$.

En otro pasaje, en el que nombra a uno de sus modelos literarios clásicos, nos muestra a Gelmírez regresando indemne a Compostela, donde es recibido con júbilo por los ciudadanos como si se tratase de Ulises a su regreso al hogar:

$\mathrm{Al}$ entrar éste en Compostela, aunque no había estado en prisión más que ocho días, no obstante al referir cuánto fue el gozo y cuánta la alegría en todos, no bastaría la elocuencia de Virgilio. Pues todos, hombres y mujeres, de todas las edades, se dirigieron a su encuentro y, derramando lágrimas de alegría, deseaban ver y hablar a su patrón y arzobispo... Toda la ciudad se alegra y se regocija por el que se ha librado del naufragio de Caribdis ${ }^{15}$.

El concepto del viaje es esencial en la imagen de Gelmírez que nos transmite la Historia Compostelana reflejando el lugar primordial que ocupa en el culto jacobeo, cuyo origen se enraíza en la veracidad histórica de una traslatio, y cuya centralidad como santuario apostólico se sustenta en su naturaleza como meta de una peregrinatio $^{16}$. No se le escapaba a un hombre de la estatura intelectual de Giraldo, como se desprende de su reelaboración del relato de la traslación del apóstol en la Historia Compostelana, citado al comienzo de esta sección, que la propia ciudad

13 Ibid., pp. 316-17.

${ }_{14}$ Ibid., p. 324.

15 Ibid., p. 369.

${ }^{16}$ La viajes de Gelmírez han sido el eje articulador de la reciente exposición Compostela y Europa. La historia de Diego Gelmírez, (M. CASTIÑEIRAS, ed.), Milán, Skira, 2010. 
de Santiago había surgido como una especie de Ítaca celestial a la que habían llegado unos navegantes que, al igual que Ulises, habían cruzado el Mediterráneo en una embarcación y, tras sortear a Caribdis, Escila y otros muchos peligros, habían conseguido alcanzar su destino ${ }^{17}$.

Si las referencias a la geografía mítica de Ulises en el contexto de los viajes de Gelmírez tenían un carácter figurado y metafórico, en el caso de la travesía del apóstol alcanzaban una dimensión literal de veracidad geográfica ya que la embarcación con el cuerpo santo había recorrido exactamente la misma trayectoria que la del héroe griego, quien, según las leyendas medievales, habría cruzado las columnas de Hércules adentrándose en el Atlántico en busca de una tierra prometida. Reflejando esta tradición, encontramos a Ulises en la Divina Comedia de Dante relatando desde una columna trémula de fuego las trágicas circunstancias de su último viaje ${ }^{18}$ :

Navegando de costa en costa pude contemplar al fin los límites de España, hasta Marruecos, y Cerdeña, y las otras islas que aquel mar en torno baña. Viejos y lentos nos habíamos ya hecho cuando alcanzamos la estrecha fosa donde Hércules marcó sus dos resguardos para evitar que el hombre más allá se aventurase. Sevilla dejé a mano derecha, Ceuta había ya quedado al otro lado. “ $¡ O h$ hermanos!”, exclamé, "que sufriendo cien mil peligros habéis llegado a occidente, de esta tan pequeña vigilia de nuestro sentidos que nos queda, no queráis negaros la experiencia de seguir al Sol, hacia el mundo sin gente (Infierno, XXVI, 103-126).

La caracterización in malo de Ulises en la Divina Comedia, donde es condenado a purgar eternamente sus pecados en el círculo del Infierno reservado a los falsos consejeros, contrasta con la que se desprende de la mayor parte del corpus literario de la Edad Media que sin duda Giraldo conocía, en el que, retomando una tradición alegórica iniciada en la antigüedad, se le presenta como ejemplo paradigmático de virtud y sabiduría ${ }^{19}$.

17 Giraldo toma la llamada carta del papa León IX como fuente para el relato de la traslación del apóstol, pero le inserta de forma significativa las referencias a Escila y Caribdis. Para la carta del papa León IX, véase M. C. DíAz y DíAz, "La Epistola Leonis pape de translatione Sancti Iacobi Galleciam”, Escritos Jacobeos, Santiago de Compostela, Universidade de Santiago de Compostela, 2010, pp. 133-81.

18 Para el Ulises de Dante, véase E. Bloch, "Odysseus Did not Die in Ithaca”, Homer, (G. Steiner y H. Fagles, eds.), Englewood Cliffs, NJ., Prentice Hall, 1962, pp. 81-85; P. H. DAmon, "Dante's Ulises and the Mythic Tradition”, Medieval Secular Literature. Four Essays, (W. Matthews, ed.), Berkeley, University of California Press, 1965, pp. 25-45; J. Freccero, "Dante's Ulysses: From Epic to Novel", Dante: The Poetics of Conversion, Cambridge, MA., Harvard University Press, 1986, pp. 136-51; A. DeYermond, "El Alejandro medieval, el Ulises de Dante y la búsqueda de las Antípodas", Maravillas, peregrinaciones y utopías: literatura de viajes en el mundo románico, (R. Beltrán, ed.), Valencia, Universitat de València, 2002, pp. 15-32. Véase también el excelente libro de P. Boitani, La sombra de Ulises. Imágenes de un mito en la literatura occidental, Barcelona, Ediciones Península, 2001.

19 Para las interpretaciones cristianas del mito de Ulises, deudoras en gran parte de las realizadas en el contexto del neoplatonismo, véase H. RAHNER, "Ulises atado al mástil”, Mitos griegos en interpretación cristiana, Barcelona, Herder, 2003, pp. 307-55; y J. PÉPIN, "The Platonic and Christian Ulysses", Neoplatonism and Christian Thought, (D. J. O'MeARA, ed.), Norfolk, VA, Internacional Society of Neoplatonic Studies, 
Desde los inicios del Cristianismo, autores como Hipólito de Roma utilizarán episodios del mito de Ulises para introducir cuestiones dogmáticas y pastorales, coincidiendo con un momento en el que la iconografía moralizada de la Odisea tenía una presencia consolidada en las artes visuales, como demuestran los numerosos sarcófagos conservados hoy en las colecciones vaticanas (fig. 2) ${ }^{20}$. En uno de sus sermones atacando las herejías, Hipólito desarrolla una interpretación cristológica de este episodio que marca la pauta para su fortuna exegética posterior:

Las enseñanzas de los herejes se parecen a un mar agitado por la violencia de los vientos. Los oyentes deberían por ello dejarlas de lado para ir en busca del puerto bien resguardado, ya que se trata de un mar lleno de monstruos y peligroso como puede serlo, por ejemplo, el mar de Sicilia, en el que se colocan seres fabulosos, el Cíclope, Caribdis, Escila y la montaña de las sirenas. Ulises... atravesó este mar devolviendo ingeniosamente a estos seres irascibles la moneda de su astucia. Las sirenas, en particular, los engañaban con sus cantos melodiosos e intentaban atraerlos con sus voces agradables. Sabiéndolo, Ulises, según dicen, tapó con cera los oídos de sus compañeros y él mismo se hizo atar al mástil, de esta forma pasó sin peligro junto a las sirenas sin dejar de escuchar sus cantos. Aconsejo a los lectores que hagan lo mismo: a causa de su debilidad deben taparse los oídos para atravesar las enseñanzas de las herejías, sin escuchar las palabras aduladoras que, como el canto armonioso de las sirenas, podrían fácilmente seducirles; o bien que se

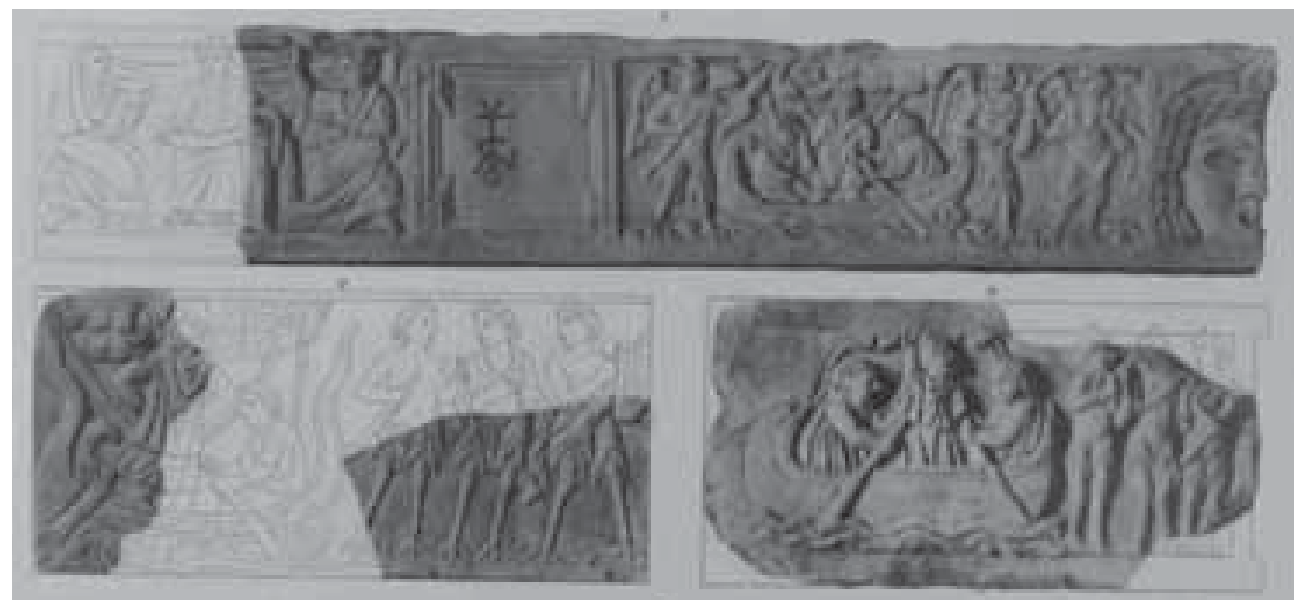

Fig. 2. Fragmentos de sarcófagos con escenas de Ulises y las sirenas.

Foto: A Wilpert, I Sarcofagi Cristiani Antichi, volume primo, tavole (Roma, 1929), tabla XXV.

1982, pp. 3-18. Para un penetrante estudio de la presencia subyacente y velada de temas del mito de Ulises en el pensamiento de San Agustín, véase R. J. O'Connell, Soundings in St. Augustine's Imagination, Nueva York, Fordham University Press, 1994.

${ }_{20}$ Para estos sarcófagos y las diferentes teorías sobre su adscripción religiosa y simbolismo, véase J. WILPERT, I sarcofagi cristiani antichi, 3 vols., Roma, 1929-1936; P. COURCELLE, "Quelques symboles funéraires du néo-platonisme latin. Le vol de Dédale -Ulysse et les Sirènes", Revue des études anciennes, 46.1 (1944), pp. 65-93; y T. KLAUSER, "Studien zur Entstehungsgeschichte der christlichen Kunst VI. Das Sirenenabenteuer des Odysseus -ein Motiv der christlichen Grabkunst", Jahrbuch für Antike und Christentum, 6 (1963), pp. 71-100. 
aten al madero de Cristo, escuchándolo con fe, para no dejarse turbar y, poniendo su confianza en aquél a quien están fuertemente atados, permanezcan de pie, rectos y firmes ${ }^{21}$.

En los escritos de otras figuras claves de la patrística, como San Jerónimo, San Ambrosio, o Máximo de Turín se perfilan las líneas fundamentales de la exégesis de este episodio que se repetirán a largo de toda la Edad Media debido a su eficacia para exponer complejos dogmas evangélicos ${ }^{22}$. El mar por el que navega Ulises representa la existencia terrena, el saeculum, que el hombre tenía que atravesar para poder regresar a Ítaca, el paraíso del que el primer hombre había sido expulsado. El mástil al que se ata Ulises es una figura de la cruz y, a la vez, del cristiano salvado por el madero sobre el que se sacrificó el hijo de Dios. Los compañeros de Ulises son sus seguidores más distantes a los que sin embargo alcanza la sombra redentora de la cruz, como había ocurrido con el buen ladrón, mientras que la cera con la que tapa sus oídos representa las Sagradas Escrituras ${ }^{23}$.

Todas estas ideas se recogen en una de las obras más populares y representativas de la época en la que escribía Giraldo, el Speculum Ecclesiae de Honorio de Autun, un compendio de sermones ávidamente leído y usado como guía para la creación de motivos figurativos en algunos de los grandes programas iconográficos del siglo XII:

Se dice que Ulises es el ejemplo paradigmático del hombre sabio. Navega a salvo frente a las sirenas, porque aquel cristiano que es verdaderamente sabio flota en el barco de la iglesia sobre el mar de este mundo. Se ata con el temor de Dios al mástil del barco, esto es, la cruz de Cristo, sella los oídos de sus compañeros con cera, esto es, la Encarnación de Cristo, de forma que éstos puedan desdeñar en su corazón los vicios y los deseos sensuales y esforzarse únicamente en alcanzar los bienes celestiales ${ }^{24}$.

Curiosamente también del entorno en el que se movía Giraldo nos ha llegado otro documento de carácter legal donde se muestra cómo la utilización de las fábulas de los gentiles con motivos pastorales, y especialmente del imaginario de la Odisea, tenía el refrendo oficial. Se trata de un capítulo del Polycarpus, una colección de cánones compilada por el Cardenal Gregorio de San Crisógono en Roma y regalada al arzobispo Diego Gelmírez, donde se cita expresamente un famoso pasaje procedente del tratado de San Ambrosio "Sobre la fe" en el que el autor de-

${ }^{21}$ Hipólito de Roma, Refutación de todas las herejías, en Los gnósticos II, Madrid, Gredos, 2002, p. 179.

22 Para San Jerónimo, véase Dom P. Antin, "Les sirènes et Ulysse dans l'oeuvre de Saint Jérôme", Revue des Études Latines, 39 (1961), pp. 232-41.

${ }^{23}$ Para un resumen de estos argumentos, véase Pépin, "The Platonic and Christian Ulysses..." op. cit.

${ }^{24}$ Citado en H. VRedeveld, "Deaf as Ulysses to the Siren's Song": The Story of a Forgotten Topos", Renaissance Quarterly, 54. 3 (2001), pp. 846-882, esp. p. 858. Aquí Honorio está recogiendo partes de la interpretación ya canónica de San Ambrosio, amplificada con gran efecto en un famoso sermón de Máximo de Turín. 
fiende el uso didáctico de metáforas y figuras mitológicas procedentes de la literatura clásica aduciendo como precedente su utilización en las Sagradas Escrituras ${ }^{25}$ :

Y si por haber mencionado a la Hidra y Escila a modo de comparación para enseñar que debemos tener cuidado tanto de los tentáculos de la infidelidad, como de los naufragios, alguno cree que esta forma de adornar nuestro discurso es un préstamo ilícito de las fábulas poéticas, esto demuestra que, al no poder atacarme por nuestra fe, deciden atacarnos por la dimensión poética de nuestro lenguaje, y a ellos debes decirle que no sólo frases, sino versos completos de los poetas se encuentran en las Sagradas Escrituras. ¿De donde deriva sino el verso "Nosotros somos verdaderamente su descendencia" que cita Pablo, conociendo los usos de la escritura profética? De hecho el discurso de carácter profético no rehusa hablar de Gigantes ni del valle de los Titanes. E Isaías habló de las sirenas y de las hijas de las avestruces, y Jeremías dijo, al profetizar sobre Babilonia, que las hijas de las sirenas habrían de habitarla, para mostrar que los atractivos de Babilonia, esto es, del tumulto de este mundo, deben relacionarse con las historias de lujuria de los antiguos mitos, las cuales parecen entonar una melodía dulce sobre los acantilados de esta vida, pero a la vez mortífera porque captura las almas de los jóvenes -el mismo poeta griego nos dice que el hombre sabio rehuye de ellas atándose, como diríamos, a las cadenas de su prudencia y pasa por esos cantos sin escucharlos ${ }^{26}$.

No es extraño por lo tanto que la gran catedral que Gelmírez, Giraldo y los otros miembros de la canónica, estaban construyendo en el centro de peregrinación más importante de Occidente albergue la representación más espectacular del Odysseus christianus en el corpus del arte medieval. Se encuentra en una columna de mármol conservada en la actualidad en los museos catedralicios, procedente de la portada norte del transepto, conocida en la Edad Media como la Porta Francigena (fig. 3$)^{27}$.

25 Para el Polycarpus (Biblioteca Apostólica Vaticana, Lat. 1354, ca. 1110), véase la ficha de catálogo, con bibliografía actualizada, de V. Nodar, "Polycarpus", en Santiago y Europa..., op. cit., pp. 354-55, este autor, haciéndose eco de interpretaciones anteriores, afirma que la connotación negativa de las figuras de tema mitológico de la Porta Francigena, como la sirena y el centauro, "se entiende a través de la lectura de pasajes [del Polycarpus] en el que se prohibía a los obispos leer libros paganos ya que sus fábulas mitológicas tenían un efecto nocivo en las almas". Sin embargo, como veremos, el sentido del mencionado pasaje es el contrario.

26 Ambrosio de Milán, De Fide, Milan, Biblioteca Ambrosiana, 1984, pp. 192-95. Este tratado didáctico fue escrito a petición del emperador Graciano para su propia instrucción católica. El pasaje citado en el Polycarpus pertenece al libro tercero, donde Ambrosio articula una defensa del uso de fábulas paganas con carácter didáctico.

27 El estudio que sentó las bases para la reconstrucción del programa iconográfico de la Porta Francigena, destruida en el siglo XVIII, es S. Moralejo, "La primitiva fachada norte de la catedral de Santiago", Compostellanum, XIV. 4 (1969), pp. 623-68. Recientemente M. Castiñeiras ha retomado el tema publicando una serie de trabajos en el marco de los cuales ha realizado una reconstrucción hipotética en 3D de la portada, véase su contribución en este volumen, con bibliografía previa, M. CAstiñEIRAs, "La Porta Francigena: una encrucijada en el nacimiento del gran portal románico". Para la identificación de la iconografía de la columna de Ulises, véase F. Prado-VILAR, "Nostos: Ulises, Compostela y la ineluctable modalidad de lo visible", en Compostela y Europa..., op. cit., pp. 260-9. La discusión que sigue expande argumentos apuntados en este estudio previo, poniendo el análisis del discurso visual de la columna en una perspectiva cultural y artística más amplia en relación con la tradición jacobea, la historiografía compostelana y el programa iconográfico general de las portadas de la catedral. 


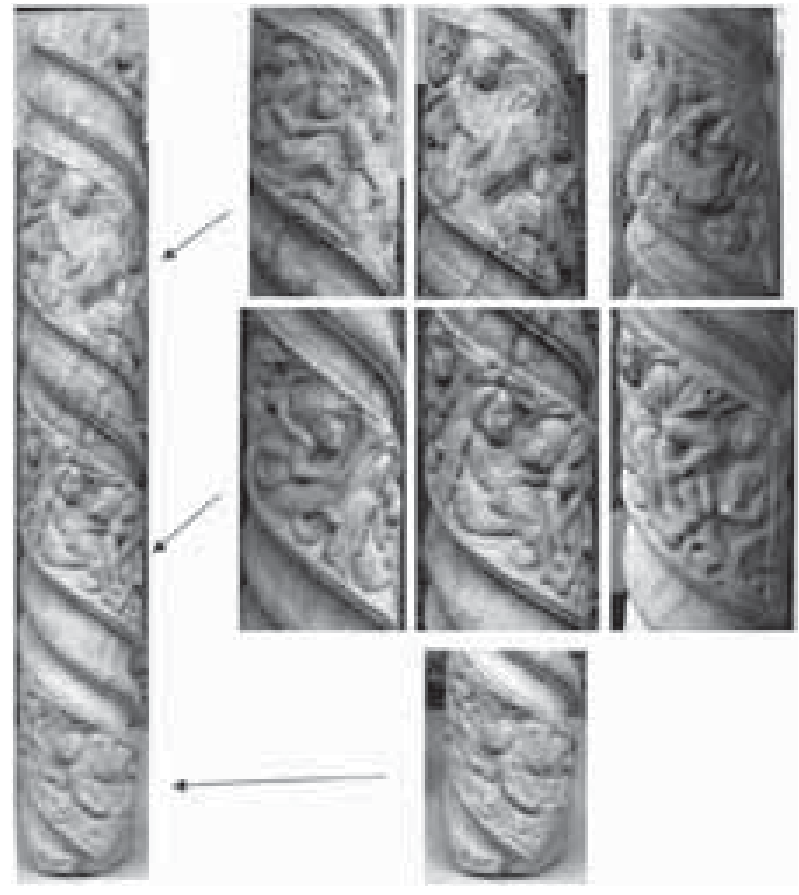

Fig. 3. Columna procedente de la Porta Francigena (ca. 1105). Museo de la Catedral de Santiago de Compostela.
Esta era la entrada a través de la cual accedían al templo los innumerables peregrinos que, tras haber recorrido un largo camino salpicado de tentaciones y peligros, se acercaban a la tumba de Santiago, el apóstol cuyo cuerpo, al igual que Ulises, el omnium peregrinus (el peregrino eterno) como lo denomina el mitógrafo Fulgencio trazando la etimología del nombre griego de Ulises a olonxenos (Mythologies 2.8), había cruzado las columnas de Hércules para descansar eternamente en los confines occidentales del mundo cono$\operatorname{cido}^{28}$.

En los cuatro registros helicoidales del fuste se despliega un sermón en imágenes compuesto, en su núcleo cen-

tral, por episodios cristianizados de la epopeya de Ulises. En ellos se combina un discurso moralizante presentando a Ulises como el ejemplo modélico de peregrino que, superando las tentaciones del camino, consigue alcanzar su meta espiritual, con una exposición doctrinal en clave tipológica sobre la Encarnación de Cristo y el papel de la iglesia en la odisea cristiana de la salvación. Fue Serafín Moralejo quien, a pesar de no haber alcanzado a precisar el tema iconográfico de la columna, proporcionó la clave para el entendimiento del funcionamiento fluido de su discurso visual al indicar que cada escena no ha de verse a través del "craso positivismo de la documentación libresca" sino que constituye un "tema de encuadre... un sucinto núcleo argumental susceptible de variados desarrollos o comentarios orales en cuanto su circunstancialidad" 29 .

En el registro central se recapitulan las líneas principales de la interpretación cristológica del episodio de Ulises en su confrontación con Escila y las sirenas,

28 L.G. Whitbread, (trad.), Fulgentius the Mythographer: On the Ages of the World and of Man; The Exposition of the Content of Virgil; The Mythologies; Super Thebaiden, Columbus, Ohio State University, 1971, p. 31.

29 S. Moralejo, "Artes figurativas y artes literarias en la España medieval: Románico, Romance y Roman”, Boletín de la Asociación Europea de Profesores de Español, 17, 32-33 (1985), pp. 61-70, esp. p. 69. 
incidiendo en la metáfora del acto salvífico de cubrir con cera los oídos de sus seguidores (fig. 4). Vemos a Ulises, caracterizado como un soldado medieval, extendiendo su brazo izquierdo con un gesto protector en torno a la cabeza de un acompañante hasta cubrir su oído con la mano, apartándolo así de la amenazante presencia de una mortífera sirena ${ }^{30}$. Entre los numerosos paralelos textuales contemporáneos que se pueden citar para clarificar el significado de la imagen cabe señalar un pasaje del llamado Tercer Mitógrafo Vaticano:

Cuando Ulises estaba a punto de pasar por el lugar de las Sirenas, selló los oídos de sus compañeros con cera, se ató al mástil y cruzó ileso frente a ellas... Las sirenas, entonces, son la manifestación de las seducciones del cuerpo... Pero el hombre sabio sella los oídos de sus seguidores, para que no puedan oír sus cantos, esto es, los instruye con preceptos salvíficos para que no se vean enredados en los placeres mundanos. Sin embargo, él mismo, cruza delante de ellas atado al mástil, esto es, sosteniéndose en la virtud. Aunque conoce las atracciones en toda su variedad mundana, las desprecia y dirige el timón firmemente hacia la patria de la felicidad eterna ${ }^{31}$.
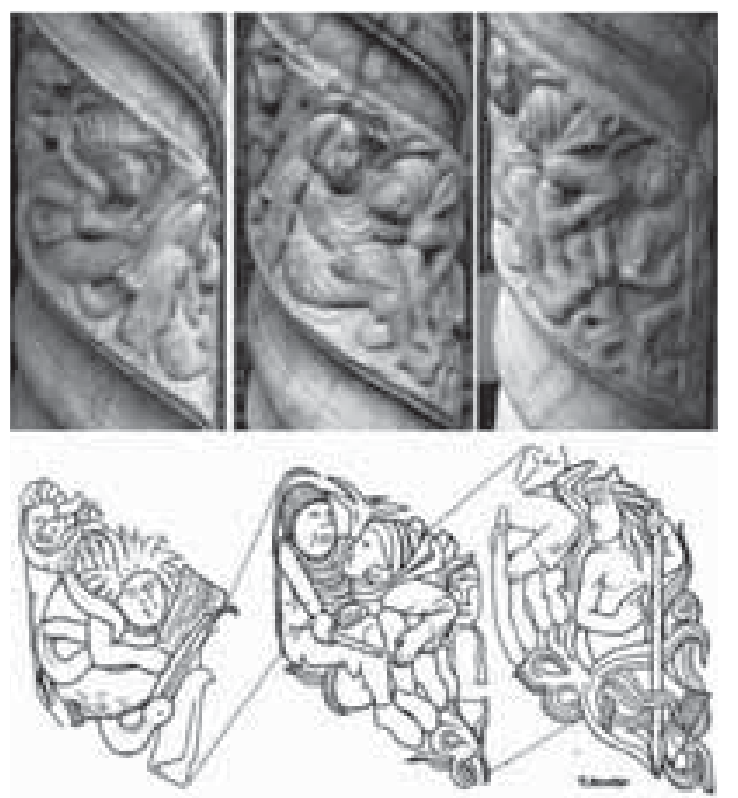

Fig. 4. Columna procedente de la Porta Francigena (ca. 1105), registro central. Museo de la Catedral de Santiago de Compostela.
Al otro lado, los dos hombres están acosados por un monstruo marino femenino cuyo diseño está claramente inspirado, al igual que el que aparece en el registro superior (cfr. fig. 13), en descripciones de Escila como la que nos ofrece el mitógrafo Fulgencio, quien la interpreta como encarnación de la lujuria:

Del vientre de la Escila salen lobos y perros marinos salvajes. Escila en griego significa violencia y ¿qué es la violencia sino la lujuria?... Escila es el símbolo de una prostituta...está llena de lobos y perros, porque no puede satisfacer sus partes púdicas con ningún otro tipo de penetración. Ulises consiguió escapar de ella inmune porque la sabiduría desprecia la lujuria (Mythologies 2.9). ${ }^{32}$

30 Para otra representación de Ulises como un soldado medieval en el s. XII, véase HerRad DE LANDSBERG, Hortus Deliciarum, 2 vols., Londres, Warburg Institute, 1979, pp. 365-66; y PrADO-VILAR, “Nostos... ”, op. cit, p. 263.

31 E. Pepin (trad.), The Vatican Mythographers, New York, Fordham University Press, 2008, p. 306. Sobre el Tercer Mitógrafo Vaticano, cuya obra se conserva en un numero considerable de manuscritos de los siglos XII al XV, véase C. S. F. BuRnetT, "A Note on the Origins of the Third Vatican Mythographer", Journal of the Warburg and Courtauld Institutes, 44 (1981), pp. 160-6.

32 Whitbread, Fulgentius the Mythographer..., op. cit., p. 74. 


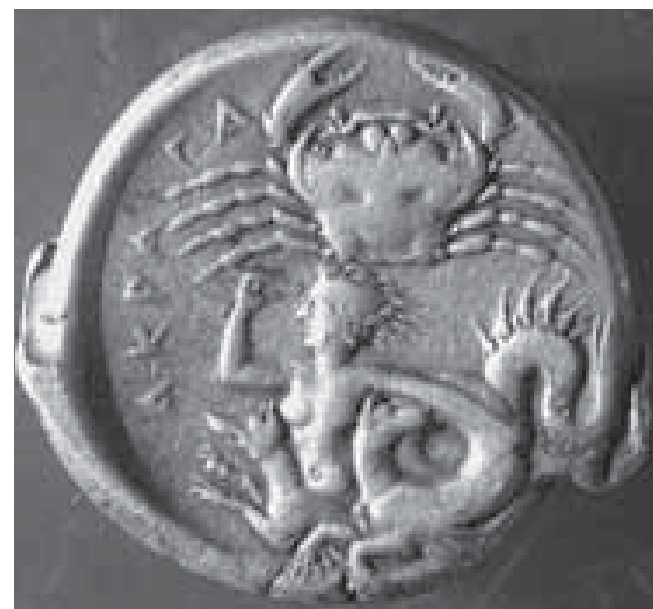

Fig. 5. Tetradracma de Akragas (Agrigento), ca. 414 a. C. Madrid, Real Academia de la Historia

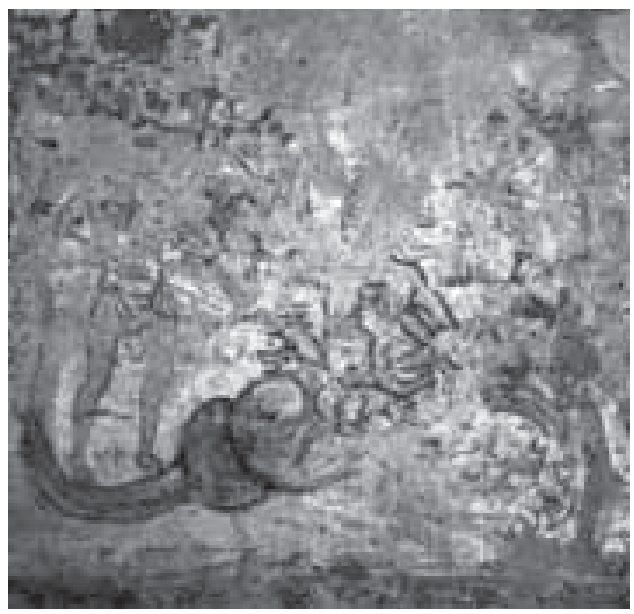

Fig. 6. Ulises y Escila. Fresco del nártex de la Abadía de Corvey, ca. 825.

De esta forma, la feroz Escila, quien va escoltada por otra grotesca sirena con patas de ave, aparece representada con la actitud y atributos que la caracterizan desde época clásica, sujetando la cola a modo de timón y rodeada de criaturas voraces que emergen de su cintura, como se ve en los tetradracmas de Agrigento (fig. 5) y en multitud de obras posteriores a lo largo de la Edad Media, como el famoso fresco del nártex de la abadía de Corvey (fig. 6) (33 $^{33}$.

El proceso de diseño del maestro de Ulises compostelano se nos revela con claridad a través de los esquemas de Moralejo quien, al igual que Schapiro utilizó el dibujo para hacer inteligibles sus observaciones formales. Descubrimos a un artista cuya inventiva y ductilidad está enraizada en una tradición que tiene como ilustre precursor al extraordinario dibujante del salterio de Corbie (fig. 7) (Bibliothèques d'Amiens Métropole, MS 18C) $)^{34}$. Para ilustrar el salmo De profundis el miniaturista carolingio concibe una inicial D que se transfigura en una representación sintética del episodio de Jonás siendo engullido por el monstruo marino, en la que el cuerpo de éste se contorsiona hasta dibu-

33 Para un tetradracma de Agrigento en la Real Academia de la Historia (cat. $\mathrm{n}^{\circ}$ 80), véase M. VICO, Monedas griegas, Madrid, Real Academia de la Historia, 2006, p. 59. Para el fresco de Corvey, véase G.M.A. Hanfmann, «The Scylla of Corvey and Her Ancestors», Dumbarton Oaks Papers, 41 (1987), pp. 249-60; y el estudio general de P. CABrera Bonet, "Del mar y sus criaturas. Seres híbridos marinos en la iconografía suritálica", Seres híbridos: apropiación de motivos míticos mediterráneos, (I. IzQuIERdo y H. Le MEAuX, eds.), Madrid, Ministerio de Educación, Cultura y Deporte, 2003, pp. 111-42.

34 Véase H. Pulliam, "Eloquent Ornament: Exegesis and Entanglement in the Corbie Psalter", Studies in the Illustration of the Psalter, (B. CAssidy and R. Muir Wright, eds.), Stanford, Shaun Tyas, 2000, pp. 24-33; y M. Holcomb y L. Bessette, eds., Pen and Parchment: Drawing in the Middle Ages, Nueva York, Metropolitan Museum of Art, 2009, pp. 36-8, con bibliografía actualizada. Para un magistral estudio del dibujo como ámbito íntimo de expresión dentro del corpus de un artista, véase L. BARKAN, Michelangelo: A Life on Paper, Princeton, Princeton University Press, 2010. 


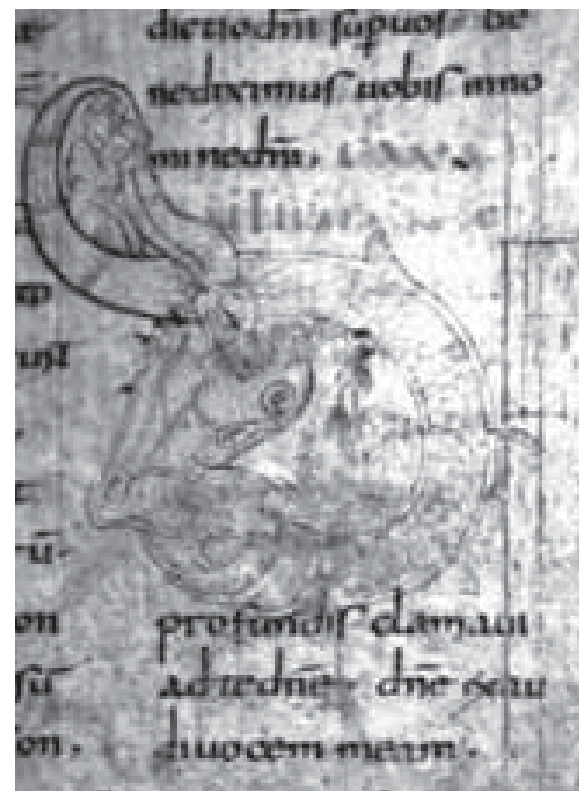

Fig. 7. Inicial del salmo 119, Salterio de Corbie, ca. 800. Amiens, Bibliothèques d'Amiens Métropole, Ms. 18C, fol. 110r.

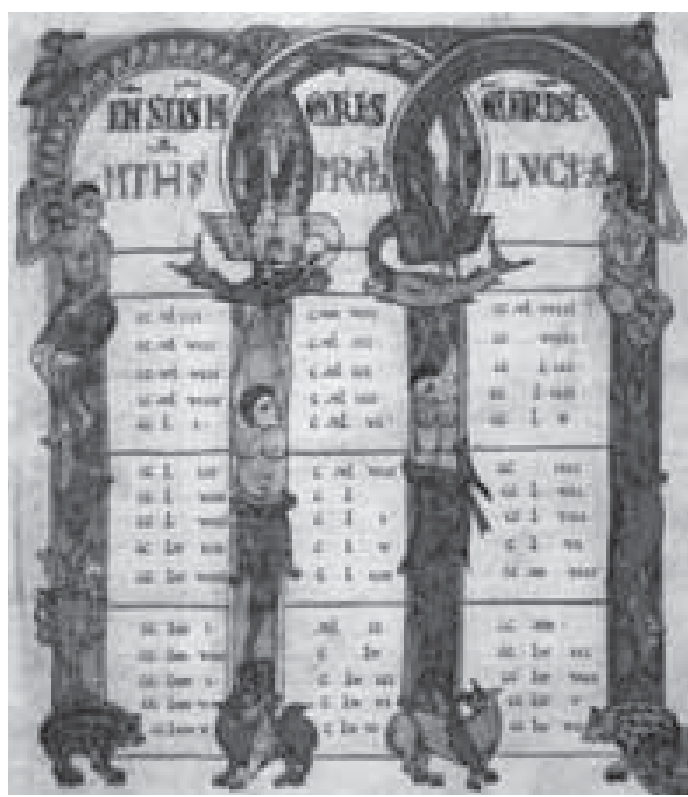

Fig. 8. Tabla de Cánones de Evangeliario. Perpignan, Bibliothèque municipale, Ms. 1, fol. 12v.

jar el perfil de la nave desde la que es arrojado Jonás. Por medio de una metamorfosis sin solución de continuidad se crea un motivo en forma de 8 que expresa, en la pura abstracción del circuito cerrado ad infinitum de su trazado geométrico, el contenido fundamental del salmo y de la exégesis del episodio bíblico, la resurrección y pervivencia eterna del alma más allá de la muerte. Heredero brillante de esta tradición, el maestro compostelano representa al Ulises cristomimético del registro central de la columna apoyado sobre un soporte que se curva en torno a su cabeza formando un halo en una suerte de stream of consciousness visual -un proceso de metamorfosis figurativa por medio del que también se recrea el mástil cruciforme-. Un ejemplo más cercano al ambiente artístico del que bebe el maestro de Ulises nos lo ofrecen las tablas canónicas de un evangeliario procedente del entorno de los Pirineos que muestran una arquitectura a base de fustes columnarios y capiteles recorridos por peces, crustáceos, aves marinas, atlantes y personajes híbridos del inframundo del thiasos dionisíaco (fig. 8) (Perpignan, Bibliothèque Municipale, ms. 1, fol. 12v. ( $^{35}$.

Si esta escena condensa magistralmente las interpretaciones alegóricas del mito de Ulises en clave cristológica, al presentar al héroe tapando con cera los oídos de un seguidor como una prefiguración del misterio de la Encarnación de Cristo y de su papel en la Redención del hombre, la que se encuentra en el registro

35 Véase La France romane au temps des premiers capétiens (987-1152), catálogo de exposición, (D. Gaborit-Chopin, coord.), Paris, Musée du Louvre editions, 2005, pp. 246-47. 
inferior parece incidir en la dimensión eclesiológica de la exégesis cristiana del nostos del héroe, a la que también hacía referencia la glosa de Honorio de Autun anteriormente citada (fig. 9). Un caballero dormido navega sobre las procelosas aguas de este mundo en una embarcación marcada de nuevo con un mástil cruci-

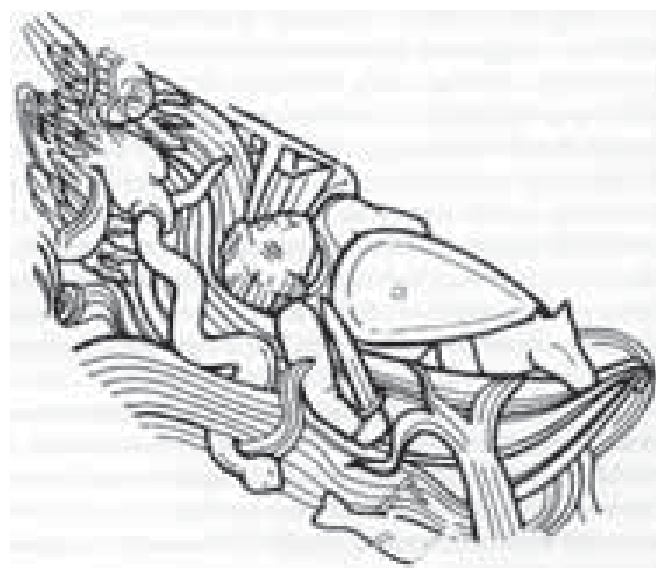

Fig. 9. Dibujo del registro inferior de la columna procedente de la Porta Francigena (ca. 1105), por Serafín Moralejo.

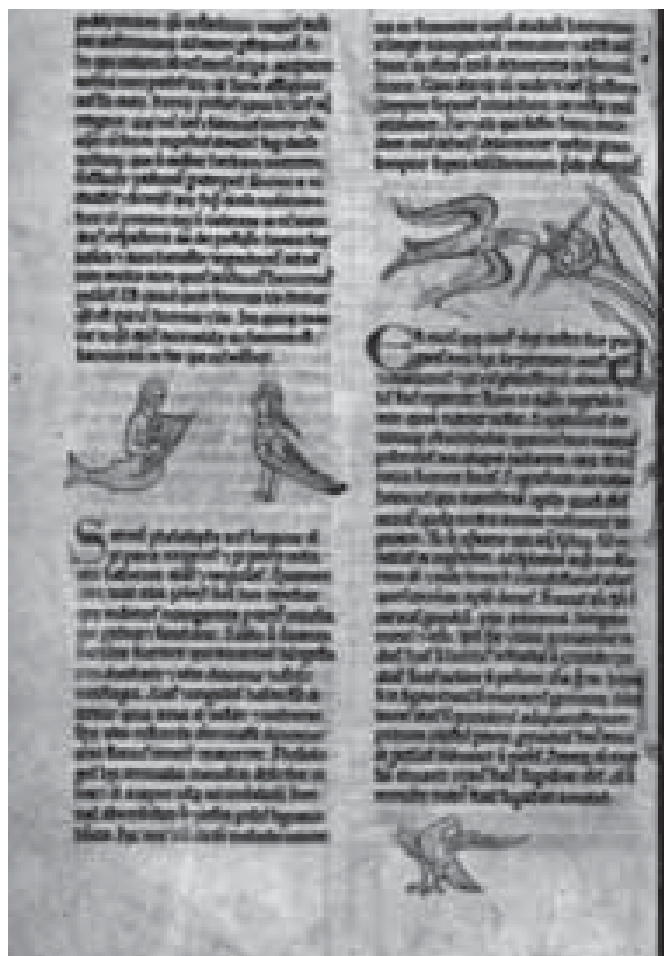
forme, mientras que un gran ibis, con su cuerpo de águila, poderosas garras y pico curvo, se lanza a la captura de una serpiente marina. Según el Bestiario, el ibis vive cerca del agua alimentándose de reptiles, carroña y animales muertos porque, al no saber nadar, no puede acceder al pescado fresco que habita en aguas más profundas. Por eso en la moralización de los Bestiarios, como se aprecia en un manuscrito del siglo XII donde se ilustra la actividad carroñera de este animal al lado de un mar habitado otras criaturas peligrosas como las sirenas (fig. 10), el ibis simboliza al hombre que sucumbe a los vicios su-

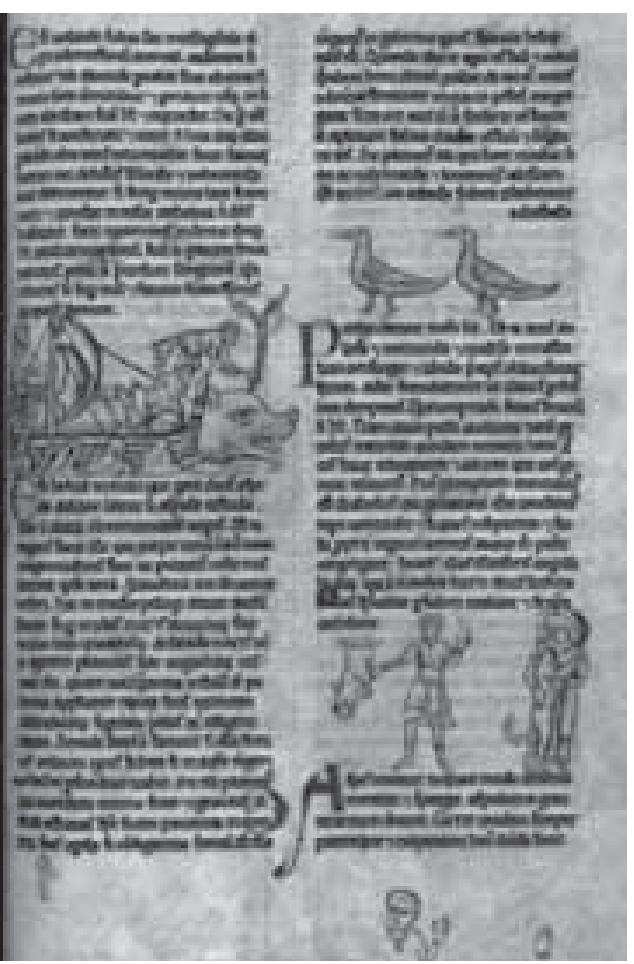

Fig. 10. Bestiario, s. XII. Cambridge, Parker Library, Corpus Christi College, Ms. 22, ff. 167v-168r 
perficiales del mundo y es incapaz de realizar la larga travesía necesaria para alcanzar las aguas puras de la doctrina cristiana. Es precisamente en el contexto de las moralizaciones del episodio de las sirenas en el ámbito de los Bestiarios donde se encuentran los paralelos más claros para el motivo del guerrero dormido, ya que los cánticos de estas sumían a los navegantes en un profundo sueño con el fin de provocar su naufragio, como se ve en el Fisiólogo de Götteweig (fig. 11) ${ }^{36}$.

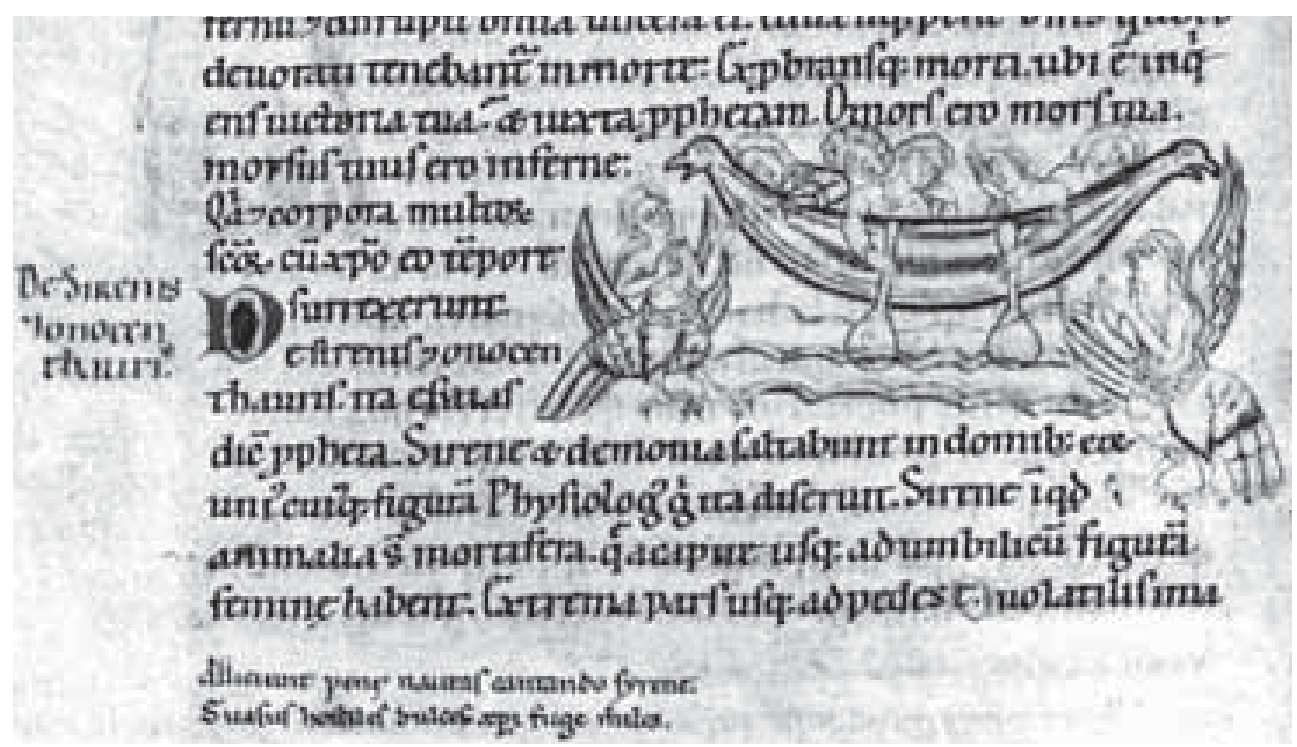

Fig. 11. Fisiologo de Götteweig, primera mitad del s. XII. Nueva York, Pierpont Morgan Library, Ms. 832, fol. 3v.

Al igual que el resto de las imágenes de la columna, donde se aprecia una relación fluida entre el pre-texto narrativo moralizante y su realización visual, la figura de la barca flotando sobre las aguas del saeculum tiene la capacidad de adquirir significados polivalentes y servir para amplificaciones exegéticas similares a las realizadas en el contexto de la composición de sermones orales, al recordar a la vez, no sólo la travesía del alma del cristiano en su camino hacia la salvación, sino también la iconografía de la milagrosa traslación del apóstol, difundida "de mano en mano" a través de las monedas acuñadas en la ceca compostelana (fig. 12) ${ }^{37}$. En efecto, en uno de los sermo-

\footnotetext{
36 Para el Fisiologo de Götteweig, véase J. LeCLERQ-MAX, La sirène dans la pensée et dans l'art de l'Antiquité et du Moyen Âge: du mythe païen au symbole chrétien, Bruselas, Académie Royale de Belgique, 1997, pp. 121-30. En la representación del episodio moralizado de Ulises en el Hortus Deliciarum de Herrade de Landsberg también se recoge la escena de la dormición de los navegantes, véase Prado-VILAR, “Nostos... ”, op. cit., p. 263.

37 La moneda de la ceca compostelana descubierta en la necrópolis de Adro Vello (O Grove, Pontevedra), que muestra en el reverso la imagen más antigua de la traslación del Apóstol, data del reinado de Fernando II de León (1157-1188), sin embargo, resulta razonable suponer que esta misma iconografía fue usada en las monedas acuñadas en la ceca que estaba activa en Santiago desde finales del siglo XI. Cualquier peregrino
} 


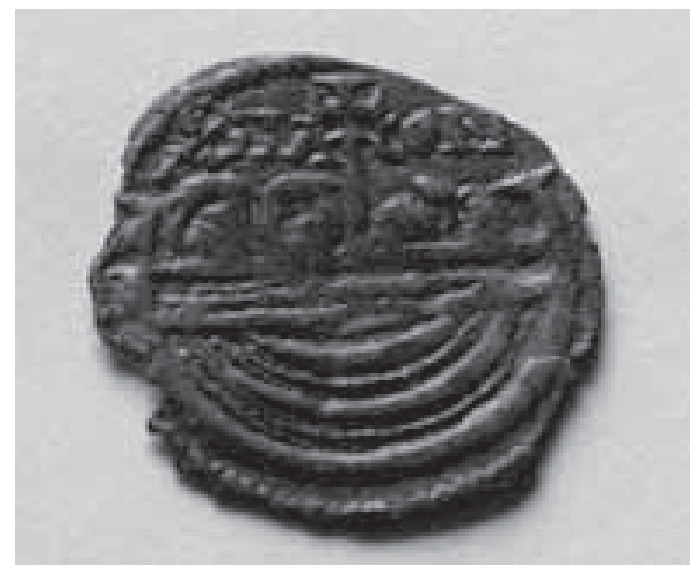

Fig. 12. Moneda de Fernando II con la traslación del apóstol Santiago, medio dinero de vellón (1157-1188). Santiago de Compostela, Museo de las Peregrinaciones. nes del Liber sancti Iacobi se utiliza la traslación del apóstol para desarrollar comentarios pastorales que podrían haber sido recitados invocando imágenes similares:

En la traslación de Santiago se significa el descanso eterno, porque del mismo modo que el cuerpo del Apóstol se traslada para su veneración desde el lugar del martirio al lugar del sepulcro y su alma es llevada por ángeles al descanso eterno; así nosotros, desde los sufrimientos de una vida virtuosa, por medio de la perseverancia en las buenas obras, subiremos indudablemente al descanso eterno del Paraíso $^{38}$.

Finalmente, en el registro superior vemos a un soldado observando impotente la escena de rapiña de un ibis acompañado de sus dos crías, una combinación frecuente en los bestiarios, que se alimentan de su caballo muerto (fig. 13). Al otro lado se cierne sobre él un monstruo que monta sobre un voraz cuadrúpedo cuya cabeza sale de su seno. El artista parece haber recurrido al imaginario de Escila para representar a su alter ego Caribdis, tan frecuentemente invocada en la Historia Compostelana, quien es descrita como un remolino huracanado que se desplaza velozmente dejando destrucción y muerte por donde pasa. Según el Tercer Mitógrafo del Vaticano:

Caribdis era una mujer muy voraz. Debido a que robó los rebaños de Hércules, le cayó un rayo de Zeus que la lanzó al mar. Allí Caribdis todavía mantiene su naturaleza anterior, porque se traga todo... ${ }^{39}$

que realizase alguna compra en el mercado situado frente a la Porta Francigena podría haber manejado una de estas monedas y ver una representación de la traslación del apóstol muy similar a la escena que se registra en la columna marmórea. Véase J. CARro Otero, "Moneda del rey D. Fernando II de Galicia-León compostelana, con el tema de la "Traslación” del cuerpo del Apóstol Santiago (1157-1188), Compostellanum, 32 (1987), pp. 575-94; ID., "Moneda de la Traslación del cuerpo del apóstol Santiago", Santiago, Camino de Europa, p. 258; y F. Alonso Romero, "La embarcación de la moneda de la necrópolis de Adro Vello (O Grove, Pontevedra)", Anuario brigantino, 10 (1987), pp. 11-16. La misma iconografía tiene su reflejo en la plástica monumental de finales del siglo XII en el tímpano de la portada sur de la iglesia de Santiago de Cereixo en la Costa da Morte.

38 A. Moralejo, C. Torres y J. Feo, trads., Liber Sancti Iacobi. Codex Calixtinus, Santiago de Compostela, Instituto Padre Sarmiento, 1951. A partir de ahora citado como Liber sancti Iacobi. Para un estado de la cuestión sobre el Códice Calixtino, con bibliografía previa, véase L. FERnÁNDEZ FERnÁNDEZ, ““... cosas tan deshonestas y feas que valiera harto más no haberlo escrito'. Avatares y memoria del Códice Calixtino”, en El Codex Calixtinus en la Europa del siglo XII. Musicología, música, arte, codicología y liturgia, Madrid, Ministerio de Cultura - INAEM, 2011 [en prensa].

39 Véase R. E. PépIN, The Vatican Mythographers, New York, Fordham University Press, 2008, p. 325. 

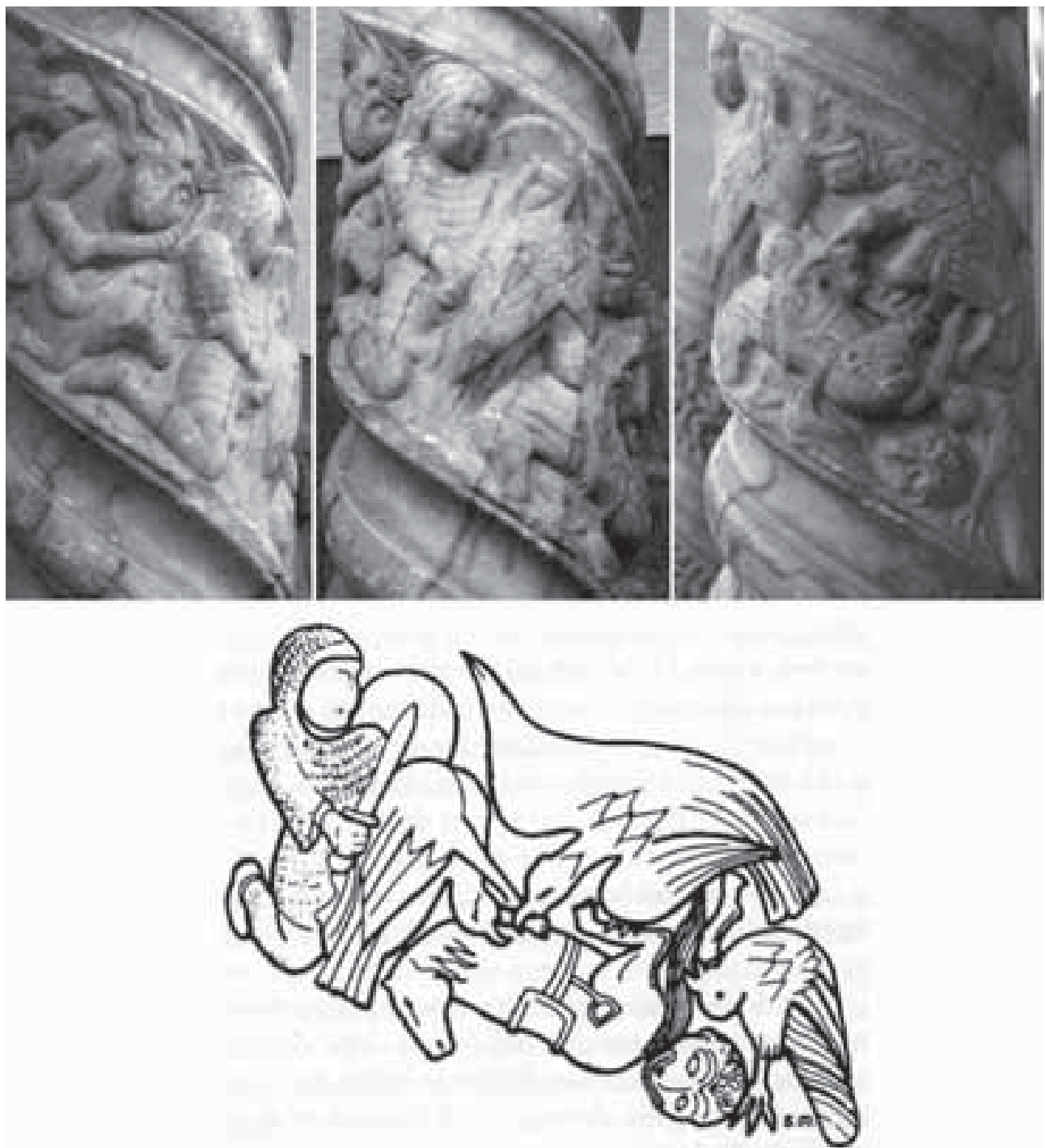

Fig. 13. Columna procedente de la Porta Francigena (ca. 1105), registro superior. Museo de la Catedral de Santiago de Compostela.

Teniendo en cuenta que el discurso moral de esta columna estaba destinado a peregrinos que recorrían el Camino de Santiago, resulta clarificador poner sus imágenes en relación con uno de los peligros principales de los que advierte la guía del Liber sancti Iacobi. En el capítulo dedicado a los "buenos y malos ríos que en el Camino de Santiago se hallan", el autor de la guía alerta al viajero para que ni él ni su caballo beban de ciertos ríos de aguas insalubres, informando de la existencia de bandas de malhechores, verdaderas aves carroñeras, que se aprovechan de un posible envenenamiento: 
En nuestro viaje a Santiago encontramos a dos navarros sentados en la orilla, que estaban afilando sus navajas, con las que solían desollar las caballerías de los peregrinos que bebían aquella agua y morían. Y a nuestras preguntas contestaron, mintiendo, que era buena para beber. Por lo cual abrevamos en ella nuestros caballos y enseguida murieron dos de ellos, que inmediatamente aquellos desollaron ${ }^{40}$.

Por lo tanto, contemplando desde la perspectiva de un peregrino las imágenes de este registro, donde se representa a un soldado al lado de su caballo muerto al borde de una corriente de agua (cuyo carácter letal quizá esté señalado por el cráneo diabólico que se dibuja en el lateral del cauce), mientras es atacado por aves carroñeras, su contenido didáctico referente a uno de los mayores peligros que le acechaban en el camino resulta evidente. Es también en esa clave topográfica moral relacionada con la geografía de la peregrinación por la se puede interpretar la presencia del monstruo Caribdis al otro lado del mismo registro, quizá una referencia a los peligrosos caminos de Aragón a los que, como hemos visto, Giraldo denomina repetidamente Caribdis:

Pero puesto que atravesar por el reino del monarca de Aragón es tan difícil y peligroso como por medio de Escila y Caribdis, sólo a fuerza de muchos ruegos pudieron conseguir que quisiera ir y se atreviera a hacerlo aquel que habían decidido enviar el obispo y la reina.... Y yo emprendí con audacia algo tan peligroso y tan arduo principalmente por amor a Santiago y por los ruegos de nuestro obispo ${ }^{41}$.

Este registro, en conclusión, es otro claro ejemplo del funcionamiento polivalente de las imágenes del fuste al presentarnos un tableau vivant de contenido moralizante que ilustra la idea de los peligros y tentaciones del mundo que asaltan al viajero.

Como veremos a continuación, todo el discurso visual de esta columna, que en su parte central muestra a Ulises como el antecedente mítico y modelo moral del peregrino que, marchando hacia Occidente entraba en la catedral atravesando la Porta Francigena (y del que el propio Apóstol, representado en la de Platerías, constituía el paradigma cristiano), está configurado siguiendo la función tipológica y la ordenación cronográfica con la que se concebían los otros ciclos iconográficos figurados en esta fachada, como los dedicados al Génesis, los meses del año y los grupos de alegorías morales y eclesiológicas. En conjunto componían una visión de la Creación del mundo, los antecedentes y la promesa de Redención que alcanzaría su realización en la Portada de Platerías con los ciclos de la Encarnación (de la que como hemos visto la historia de Ulises ofrecía un antecedente tipológico), la

40 Liber sancti Iacobi, pp. 510-13, esp. pp. 510-11.

${ }^{41}$ Historia Compostelana, pp. 315-16.Véase también: "Pero ciertamente no convenía en modo alguno despreciar la invitación del papa Calixto al concilio de Reims ni sus promesas, ni dejarlas en vano. Pero ningún canónigo de la iglesia de Santiago al que la fama de su nombre hubiera hecho célebre, se atrevía de ningún modo a atravesar por medio de las fauces abiertas, por medio de la Caribdis de España" (Historia Compostelana, p. 321). 
Pasión de Cristo, y la labor apostólica y evangélica de la iglesia. Como arquetipo del peregrino, la figura de Ulises se sumaba a la de Adán, protagonista del ciclo del Génesis, pues como ya indicó Moralejo: "En su parte doctrinal, el Liber Sancti Iacobi menciona a Adán como el primero de los peregrinos -en el sentido original de expatriado - y figura por tanto de toda una humanidad peregrina en la tierra" ${ }^{42}$.

\section{La Porta Francigena: In principio erat peregrinatio}

Testimonio excepcional de esta prolongación de la exégesis en el ámbito figurativo nos lo ofrece el mapamundi oxomense. Fruto de una geografía inseparable de la historia -no sólo como su marco de acción, sino también en cuanto por ella conformada-, nuestro mapa se abre al acontecer, a la noticia de su presente, en términos incluso coyunturales. En él tienen cabida tanto la ya mítica Troya como la palpitante actualidad de una Compostela que por entonces se afirmaba como uno de los santuarios mayores de la cristiandad ${ }^{43}$.

En uno de los artículos más importantes dentro del canon de la historiografía española, Serafín Moralejo trazó la genealogía compostelana del mapamundi del Beato de Burgo de Osma (1086) (fig. 14). La extensión de Galicia, que ocupa 3/4 de la Península Ibérica, la monumentalidad del santuario jacobeo, que supera en tamaño incluso al de San Pedro en Roma, la representación naturalista del Faro de Brigantium (actual Torre de Hércules), que entonces pertenecía al obispado de Santiago, y la exaltación de la riqueza natural de las costas gallegas, marcada por la presencia en su litoral del pez más grande de todo el orbe oceánico, nos revela un mundo construido a través de la mirada anamórfica de un autor cuyo punto focal era Santiago de Compostela ${ }^{44}$. Si en el texto de Beato el mapamundi servía como ilustración de las sortes apostolorum, los lugares de la tierra donde cada apóstol fue destinado para realizar su labor evangelizadora, se transforma en

${ }^{42}$ Santiago, Camino de Europa. Culto y Cultura en la Peregrinación a Compostela, (S. MoraleJo, coord.), Santiago de Compostela, Xunta de Galicia, 1993, p. 387.

43 S. Moralejo "El mundo y el tiempo en el mapa del Beato de Osma", en El Beato de Osma. Estudios, Valencia, Vicent García Editores, 1992, pp.151-79, esp. p. 153.

44 El "castillo de Santiago, llamado de Faro" (Torre de Hércules) se cita varias veces en el Historia Compostelana, (cfr. Historia Compostelana, p. 388). Para la formulación del concepto de mirada anamórfica en el análisis de la miniatura gótica, véase F. PRADO-VILAR, "The Gothic Anamorphic Gaze: Regarding the Worth of Others", 'Under the Influence': Questioning the Comparative in Medieval Castile (C. RoBInson y L. RouHI, eds.), Leiden y Boston, Brill, 2005, pp. 67-100. Para el mapamundi del Beato de Saint-Sever, donde se observa una similar estrategia cartográfica de reordenación del territorio reflejando los intereses de la abadía, véase A. G. REMENSNEYDER, "Topographies of Memory: Center and Periphery in High Medieval France", Medieval Concepts of the Past: Ritual, Memory, Historiography, (G. Althoff, J. Fried, P. J. Geary, eds.), Cambridge, Cambridge University Press, 2000, pp. 193-214. Véase también N. Lozovsky, "The Earth is Our Book": Geographical Knowledge in the Latin West, ca. 400-1000, Madison, The University of Michigan Press, 2000. Para el contexto hispano: P. HenRIET, "L'espace et le temps hispaniques vus et construits par les clercs (IXe-XIIIe siècle)", Annexes des CLCHM, 15 (2003), pp. 81-127; y S. SÁENz-LóPez PÉrEz, "El mundo para una reina: los mappaemundi de Sancha de León (1013-1067)," Anales de Historia del Arte, Volumen Extraordinario (2010), pp. 317-34. 

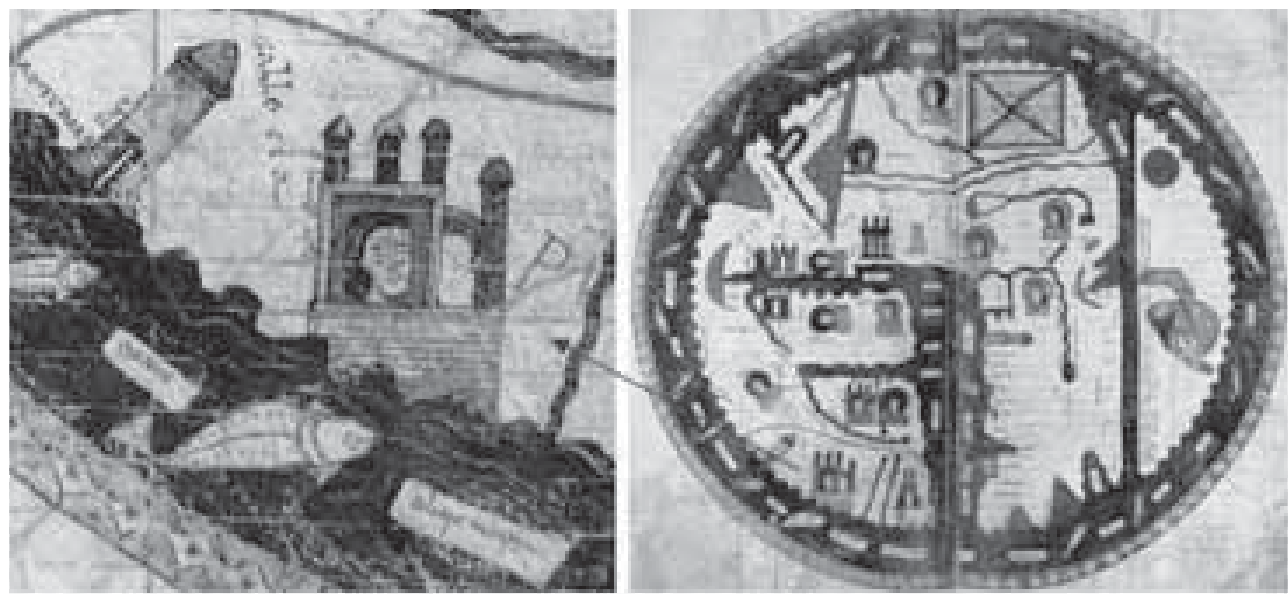

Fig. 14. Mapamundi, Beato de Burgo de Osma (1086) detalle. Catedral de Burgo de Osma, Biblioteca Capitular, cod. 1, fol. 34v.

el caso de Osma en una geografía de la peregrinación, al representar sus retratos en forma de relicarios de busto enmarcados por las arquitecturas de las basílicas donde descansan sus restos. Además de reflejar una topografía centrada en Galicia y su exaltación de la idea de peregrinación, el mapamundi de Osma incorpora alusiones a una geografía mítica vinculada estrechamente al santuario jacobeo, de la que tenemos noticia gracias a un texto latino contemporáneo que narra la navegación milagrosa del monje Trezenzonio ${ }^{45}$. Cuenta el relato cómo este monje sube a la Torre de Hércules y, con ayuda de un gran espejo allí colocado, observa en la distancia la llamada insula magna Solistitionis que Moralejo identifica con la misteriosa isla Solitio Magna representada frente a las costas gallegas en el mapamundi de Osma. Tras solicitar protección divina para el viaje, Trezenzonio construye una barca y pone rumbo a la isla, en donde se encuentra un paraíso terrenal de primavera perpetua, abundante comida y ambientado por coros angélicos. En el centro de la isla había una gran basílica decorada con piedras preciosas en cuyo interior se encontraba una columna de mármol donde se registraba la información sobre el lugar:

45 Se conserva en dos manuscritos del s. XIV procedentes de la biblioteca del monasterio de Alcobaça (Lisboa, Biblioteca Nacional, Códice Alcobacense $n^{\circ} .37$, fols. $118 v-120$ r, y Códice Alcobacense $n^{\circ} 39$, fols. 359r-360r). El texto ha sido publicado con traducciones al español y portugués por M. C. DíAz y DíAz, "Un viaje a la isla del paraíso", Visiones del más allá en Galicia durante la alta edad media, Santiago de Compostela, Bibliófilos Gallegos, 1985, pp. 95-112; A.A. NAscimento, “Trezenzónio e a Ilha do Solstício: a funcionalidade da ausência no reencontro do presente", Em torno da Idade Média, (Helder GodinHo, ed.), Lisboa, Universidade Novae Lisboa, Faculdade de Ciências Sociais e Humanas, 1989, pp. 185-96; y M.C. AlmeIda LuCAs, "Insula Solistitionis: uma ilha iniciática", A simbólica do espaço: cidades, ilhas, jardins, (Y. Centeno y Lima de Freitas, eds.), Lisboa, Estampa, 1991, pp. 73-85. Recientemente se ha publicado la primera traducción en inglés: C. VAN DUZER, "The Voyage of Trezenzonio to the Great Island of the Solstice: English Translation and Commentary”, Folklore 119.3 (2008), pp. 335-45. 
En el interior, en una columna de mármol, estaba inscrito el nombre de la basílica de Santa Tecla, el nombre de la isla del Gran Solsticio (insula magna Solistitionis), y el nombre del rio Bervecaria ${ }^{46}$.

Allí pasará siete años hasta que una voz angélica le aconseja que se marche. Al resistirse a seguir la indicación divina, el monje es castigado con lepra y ceguera por lo que finalmente se ve obligado a huir de la isla buscando, en las orillas del Miño, la protección de su antiguo mentor el obispo de Tuy Adelfius.

Por lo tanto, en una reducida sección del mapamundi de Osma encontramos reunidos el punto de partida (la Torre de Hércules), el de destino (la isla del Solsticio) y el de retorno (el Miño) del relato del monje Trezenzonio, a modo de "condensación gráfica de su aventura" ${ }^{47}$. No por casualidad, en el mismo mapa vemos registrada de forma prominente la ciudad de Troya, el punto de partida de ese otro viaje mítico que, como nos indica la Historia Compostelana y la columna de Ulises de la Porta Francigena, estaba muy presente ya a finales del siglo XI en los ambientes compostelanos donde se realizó el modelo del que deriva el mapamundi oxomense (fig. 15) ${ }^{48}$. En efecto, como ha señalado acertadamente Moralejo, los numerosos síntomas compostelanos de este mapamundi, que Barbara Shailor ha asignado al scriptorium de Sahagún basándose en evidencia paleográfica comparativa, reclaman la existencia de un prototipo galaico perdido ${ }^{49}$ :

Tal hipótesis nos permitiría... conciliar la segura procedencia de Sahagún [del Beato de Burgo de Osma] con su apasionada información sobre la realidad, intereses y fabulaciones galaicas. Imagino, en concreto, lo que pudo haber sido un Beato compuesto en Compostela durante los reivindicativos pontificados de Cresconio o de Diego Peláez, entre 1037 y 1086 , en un marco cronológico concordante para el propuesto para el relato de Trezenzonio y cuando la sede jacobea albergaba pretensiones que luego se verían frustradas ${ }^{50}$.

Otro testimonio fragmentario de ese mundo galaico de la esfera de influencia compostelana donde la cartografía de los beatos alcanzó un gran desarrollo a finales del siglo XI es el mapamundi rupestre del monasterio de San Pedro de Rocas ${ }^{51}$. Este mapa nos

46 Texto en latín en DíAz y DíAz, "Un viaje a la isla del paraíso...," op. cit., p. 117.

47 Moralejo, "El mundo y el tiempo en el mapa del Beato de Osma...," op. cit., p.166.

48 Como testimonio cartográfico del conocimiento de la navegación atlántica de Ulises, es significativa la presencia prominente en el mapamundi de Osma de Lisboa "Olisabona", ciudad que los geógrafos romanos como Estrabón o Solino creían había sido fundada por el héroe griego, véase H. DE CARLos Villamarín, "Ulises, fundador de Lisboa. Algunhas anotacions", Troianalexandrina, 2 (2002), pp 31-40. La fundación de Lisboa por Ulises se recoge en la General Estoria de Alfonso X el Sabio, una compilación del conocimiento histórico previo, en la que las peripecias de Ulises y su relación con la Península Ibérica tienen especial relevancia, véase Alfonso X EL SABIO, General Estoria, Tercera Parte, vol. 1 (P. SÁnchez-Prieto BorJA, ed.), Madrid, Biblioteca Castro, 2009, pp. $259-60$.

49 B. Shallor, "El Beato de Burgo de Osma: estudio paleográfico y codicológico", El Beato de Osma. Estudios, op. cit., pp. 35-58.

50 Moralejo, "El mundo y el tiempo en el mapa del Beato de Osma...," op. cit., p. 177.

51 Véase S. Moralejo, "El mapa de la diáspora apostólica en San Pedro de Rocas: notas para su interpretación y filiación en la tradición cartográfica de los Beatos", Compostellanum, 31, 3-4 (1986), pp. 315-40. 

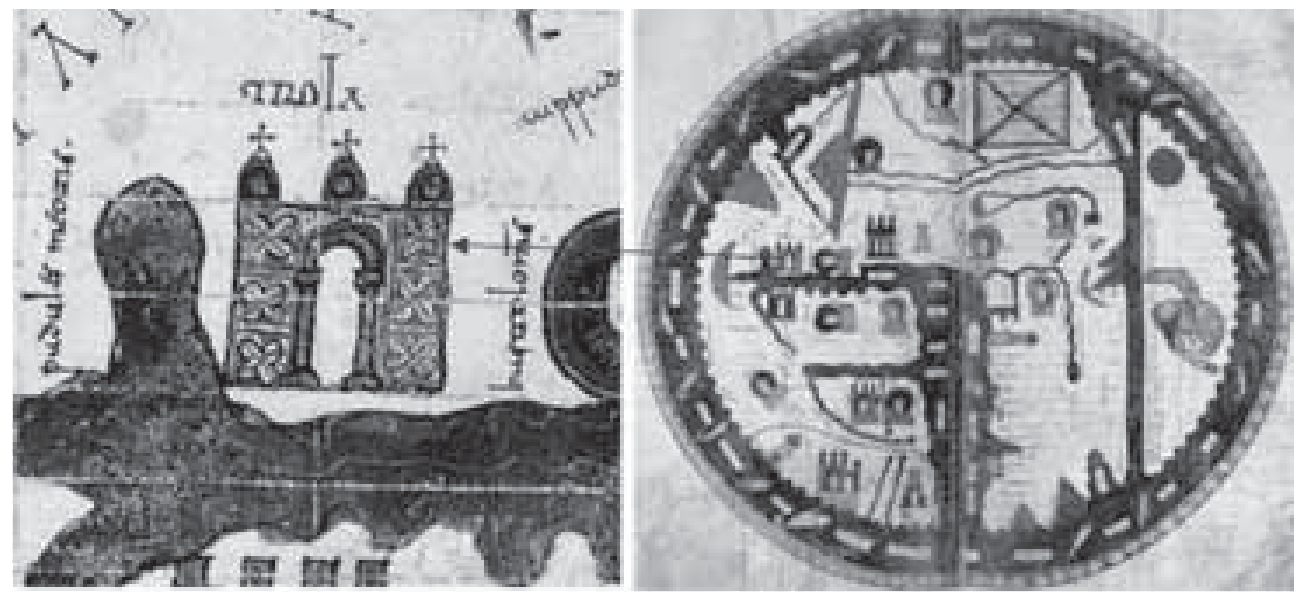

Fig. 15. Mapamundi, Beato de Burgo de Osma (1086) detalle. Catedral de Burgo de Osma, Biblioteca Capitular, cod. 1 , fol. $34 \mathrm{v}$.

permite observar el paso de un programa iconográfico del pergamino al muro, de la horizontalidad del códice destinado a la contemplación privada a la verticalidad de su transformación en una pantalla monumental sobre la que realizar una peregrinación visual:

Precisamente allí donde la stabilitas loci se ofrece como alternativa a la peregrinatio, es donde procede, por compensación, esta indicación a un viaje místico o imaginario tras las huellas paradigmáticas de los apóstoles: una forma figurativa de peregrinatio in stabilitate, ya que la peregrinación efectiva era entonces vedada o desaconsejada a los monjes, empeñados en un único destino itinerante hacia la otra Jerusalén ${ }^{52}$.

Este análisis de las condiciones de patronazgo, ideología y función del mapamundi de Osma y de su prototipo, así como su proceso de transformación en un programa monumental sobre el muro de San Pedro de Rocas, nos ayuda a delinear aspectos fundamentales del diseño de otro producto compostelano íntimamente relacionado con él, la Porta Francigena. Si el mapamundi de Osma nos presenta una cartografía centrada en Santiago y articulada en torno a la idea de la peregrinación, sacra y mítica, a Compostela, la Porta Francigena nos ofrece una cosmología que, de nuevo, tiene a Santiago y el peregrinaje, sacro y mítico, como eje definidor del devenir de la historia y del espíritu. Si el mapamundi oxomense ofrece testimonio de cómo un área periférica de la cristiandad puede ser convertida en centro a través de una geografía simbólica y mítica de lo sacro, la Porta Francigena muestra un ejemplo de cómo un santuario periférico en el contexto de la historia de la salvación se puede constituir en centro a través de una concepción de la historia universal como una sucesión tipológica de peregrinationes que anticipan la peregrinación paradigmática a Santiago

52 Moralejo, “El mapa de la diáspora apostólica en San Pedro de Rocas...”, op. cit., p. 331. 
realizada en el presente del que contempla la portada. Al igual que el mapamundi de San Pedro de Rocas, que ofrecía al monje una forma figurativa de peregrinatio in stabilitate, la Porta Francigena ofrecía al peregrino que llegaba a Compostela tras completar el camino, una pantalla de meditación que le ayudaba a entender la dimensión de su peregrinación a Santiago en el contexto general de la historia de la redención, encontrando referentes tipológicos, alegóricos y morales, empezando por Adán como primer peregrino, pasando por Ulises, como omnium peregrinus a Occidente, hasta llegar a Cristo, cuya propia ardua peregrinación por la tierra se anunciaba en esta portada. Este es el mensaje en el que incide uno de los sermones del Liber sancti Iacobi, que podría ser recitado delante de algunas imágenes de la Porta Francigena:

Adán es considerado como el primer peregrino, pues por haber traspasado el precepto de Dios tiene que salir del Paraíso y es lanzado como al destierro en este mundo... El Patriarca Abraham fue peregrino pues de su patria marchó a otro país... Nuestro Señor Jesucristo mismo, después de resucitar de entre los muertos, al volver a Jerusalén fue el primer peregrino... Los apóstoles fueron peregrinos, pues el Señor los envió sin dinero ni calzado ${ }^{53}$.

Por lo tanto, el ambicioso programa de exaltación de la sede jacobea y de la peregrinación que vemos expresado en el mapamundi oxomense en forma cartográfica, se plasma en la Porta Francigena en forma cronográfica o de historia universal.

Desde el punto de vista estructural, la presencia del episodio de Ulises en esta portada se ajusta al esquema de sincronización de la historia universal cristiana y pagana que dominaba en el occidente latino desde la sistematización de cronologías paralelas realizadas siguiendo el modelo de Eusebio-Jerónimo ${ }^{54}$. Un manuscrito del s. IX de la Cronografía de Jerónimo refleja el modelo que se copiará a lo largo de toda la Edad Media, mostrando la distribución tabular en bifolio de las cronologías paralelas de eventos bíblicos y de historia pagana (Oxford, Merton College, Merton MS. Coxe 315, fol. 51v-52r) (fig. 16). En el lado inferior derecho, frente a la página donde se recoge la historia de Sansón comparándola con las labores de Hércules, se registra el episodio de la confrontación de Ulises con Escila y las sirenas reflejando las moralizaciones habituales en mitógrafos y bestiarios: "Palaephatus escribe en el libro uno de las Cosas Increíbles aquello que dicen sobre Ulises: cómo la Escila

53 Liber sancti Iacobi, pp. 207-8.

${ }^{54}$ Las primeras historias universales cristianas surgieron por la necesidad de integrar la historia bíblica en los esquemas cronológicos de las historias paganas y establecer una concurrencia entre las dos tradiciones. Eusebio de Cesarea creo una representación sinóptica de las diversas cronologías derivadas de fuentes judías y paganas organizándolas en un formato tabular donde se podían ver las sincronías entre eventos de la historia judeo-cristiana y de la historia pagana. Esta solución pasó al occidente latino a través de la traducción realizada por Jerónimo en torno al 380. Véase M. I. Allen, "Universal History, 300-1000: Origins and Western Developments", Historiography in the Middle Ages, (D. Mauskopf DeliYannis, ed.), Leiden, Brill, 2003 , pp. 117-42; R. McKitterick, Perceptions of the Past in the Middle Ages, Notre Dame, IN., University of Notre Dame Press, 2006; W. Stevens, "A Present Sense of Things Past: Quid est enim tempus?", Time and Eternity: The Medieval Discourse, (G. Jarita y G. Moreno-Riaño, eds.), Turnhout, Brepols, 2003, pp. 9-28. 

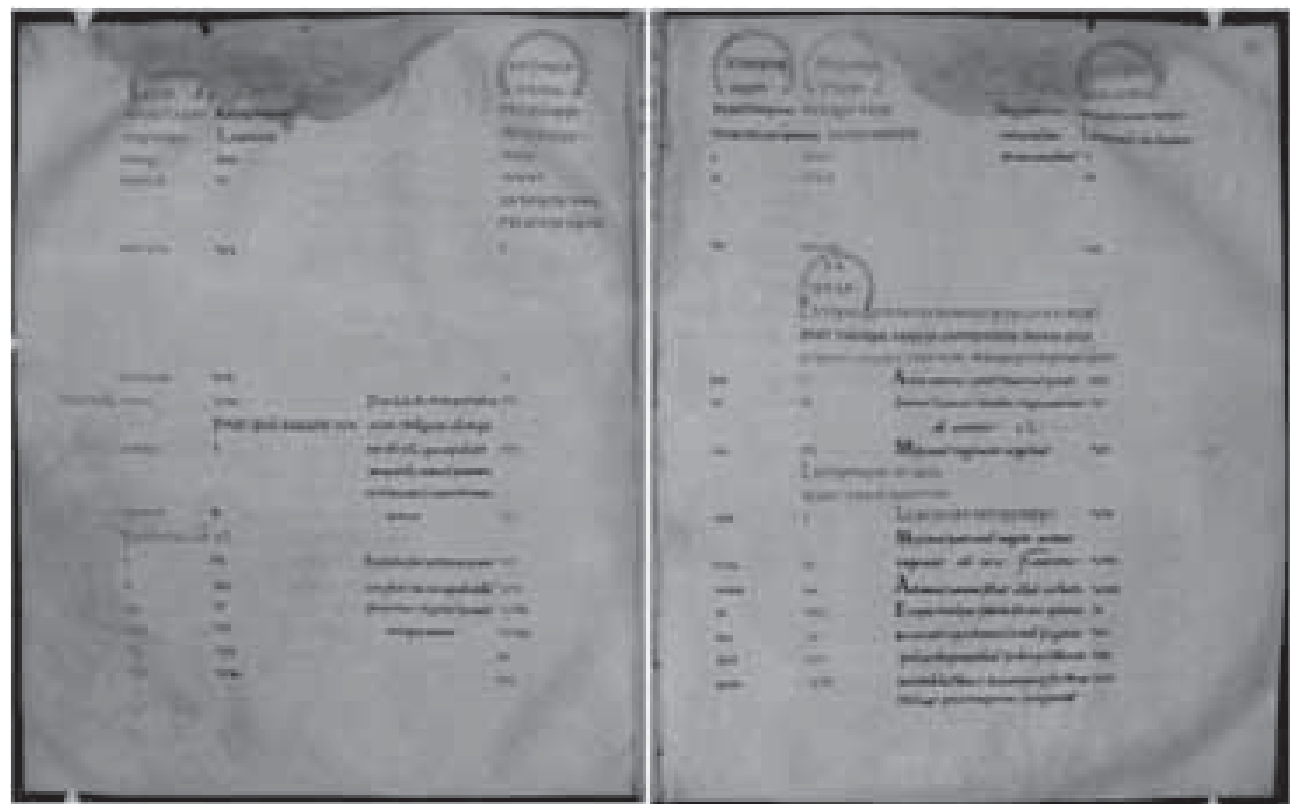

Fig. 16. Crónica de Eusebio de Cesarea traducida por San Jerónimo. Oxford, Merton College, Merton MS. Coxe 315 , fol. 51v-52r.

de la que escapó era un trirreme tirreno que acostumbraba a robar a sus pasajeros, y como las "Sirenas" eran prostitutas que solían engañar a los marineros"

Si en el caso del mapamundi de San Pedro de Rocas habíamos visto la plasmación monumental de un modelo de pensamiento cartográfico, es decir, de ordenación del mundo, surgido sobre el pergamino, las cronografías tabulares del tipo Eusebio-Jerónimo, asumidas por los autores más influyentes de la cristiandad como Isidoro o Beda, y ubicuas en todas las bibliotecas monásticas y episcopales, nos ofrecen un modelo de

55 Las Cronografías del modelo Eusebio-Jerónimo solían ser adaptadas a los intereses de los diferentes centros en los que se copiaban por medio de glosas marginales para englobar la historia local y situarla dentro de la estructura del tiempo universal y de la historia de la redención. La Historia Compostelana y el Cronicón iriense nos indican una actividad importante de producción histórica en Santiago a principios del s. XII, para la que sin duda tendrían una biblioteca de referencia en la que no podrían faltar manuscritos del modelo Eusebio-Jerónimo. Una indicación de la variedad de obras de historia que poseía la sede compostelana nos la proporciona un documento relativo a un pleito sostenido a finales del s. XII entre las diócesis de Compostela y Braga sobre la extensión de sus jurisdicciones, en el que se da una lista de libros a los que recurrieron para exponer su caso: obras de Orosio, Idacio de Chaves (su Chronicon sigue el modelo Eusebio-Jerónimo), Juan de Bíclaro, Isidoro de Sevilla, el De bello Alexandrino y De bello Gallico de Julio César, etc. Véase A. DE Jesús DA Costa, "Geórgicas de Virgílio (Fragmentos portugueses do século XI), Humanitas 7-8 (1955-1956), pp. 220-37, esp. pp. 226-27; y A. RUCQUOI, "De grammaticorum schola: La tradición cultural compostelana en el siglo XII", Visitandum est: Santos y cultos en el Codex Calixtinus (Actas del VII Congreso Internacional de Estudios Jacobeos), (P. CAuCci von SAuken, coord.), Santiago de Compostela, Xunta de Galicia, 2005, pp. 235-54, esp. p. 244. Para una interesante reevaluación del Cronicón iriense, un documento donde la mitología de Troya en relación a la sede de Íria se hace explícita, véase IsLA Frez, "Una vuelta al Cronicón iriense," Memoria, culto y monarquía hispánica entre los siglos X y XII, Jaén, Universidad de Jaén, 2006, pp. $185-220$. 
ordenación de los acontecimiento históricos, es decir, una plantilla para la organización de la estructura de la historia universal como la que subyace el programa de la Porta Francigen $a^{56}$. En esta portada, al igual que en el diseño sobre pergamino del modelo Eusebio-Jerónimo, la distribución cronológica tabular permite desarrollar lecturas tipológicas, alegóricas y morales entre diferentes episodios y personajes de la historia humana $^{57}$. En efecto, la columna de Ulises no sólo estaba perfectamente integrada con los ciclos veterotestamentarios dentro del marco cronográfico de la Porta Francigena sino que su emplazamiento visual permitía establecer con ellos una serie de relaciones tipológicas. En su reconstrucción hipotética de esta portada, Manuel Castiñeiras ha propuesto la colocación en el frontispicio del célebre relieve del Rey David vencedor sobre el mal, que hoy se encuentra encastrado en el contrafuerte izquierdo de la portada de Platerías ${ }^{58}$. Un análisis de su iconografía a la luz del programa de la columna de Ulises sugiere que ambas obras podrían haber estado relacionadas espacialmente, quizá el relieve estaría situado en el mismo eje axial que la columna, con lo cual se articularía un discurso pastoral centrado en alegorías musicales en clave moral y cristológica ${ }^{59}$. Como ha señalado Moralejo, el David compostelano sigue la tipología iconográfica derivada de la exégesis cristiana de la figura de Orfeo, aquí representado entonando la música con la que consiguió someter al spiritus malus que poseía a Saúl -una victoria contra las fuerzas demoníacas simbolizada por el ser híbrido monstruoso con patas de ave, alas y salvaje cabellera al que aplasta bajo sus pies (figs. 17 y 18$)^{60}$. Esta es una figura de magistral diseño, perteneciente a una genealogía formal de híbridos que tiene hitos cercanos en los personajes femeninos de los capiteles de la Portada del Cordero de San Isidoro de León, las mujeres monstruosas del capitel del sátiro de Jaca o la grotesca sirena del registro central de la columna de Ulises compostelana, cuyos rasgos faciales reproduce con fidelidad (fig. 19) ${ }^{61}$. Comentaristas medievales interpretaban el instrumento utilizado por David para vencer al mal, construido con madera y cuerda (en el caso santiagués una especie de fídula), como una imagen de la cruz con la que

\footnotetext{
${ }_{56}$ Para Isidoro, véase P. BASSETT, "The Use of History in the Chronicon of Isidore of Seville," History and Theory, 15 (1976), pp. 278-92; y para Beda, R. D. RAY, "Bede, the Exegete, as Historian", Famulus Christi: Essays in Commemoration of the Thirteenth Centenary of the Birth of Venerable Bede, (G. BonNer, ed.), London, 1976, pp. 125-40.

57 Véase H. DE LuBAC, Exégèse médiévale: les quatre sens de l'écriture, première partie, 2 vols., Paris, 1958.

58 CASTIÑEIRAs, "La Porta Francigena: una encrucijada en el nacimiento del gran portal románico", pp. 89-118.

59 En la General Estoria de Alfonso X, reflejando compilaciones previas, la historia de Ulises de inserta cronológicamente tras los salmos y los cánticos en la sección dedicada a "Los gentiles del tiempo de David", véase Alfonso X, General Estoria..., op. cit., pp. 147-286.

${ }^{60}$ S. Moralejo, "Saint-Jacques de Compostelle. Les Portails retrouvés de la cathédrale romane", Les dossiers de l'archeologie, 20 (1977), pp. 87-103. Véase también el ya clásico estudio de J. Block FrIEDMAN, Orpheus in the Middle Ages, Cambridge, MA, Harvard University Press, 1970.

${ }^{61}$ Para la Portada del Cordero de San Isidoro de León, con bibliografía previa, véase F. Prado-VILAR, "Lacrimae rerum: San Isidoro de León y la memoria del padre", Goya, 328 (2009), pp. 195-221. Para el capitel del sátiro de Jaca, véase ID., "Diario de un argonauta...”, op. cit., pp. 95-107.
} 


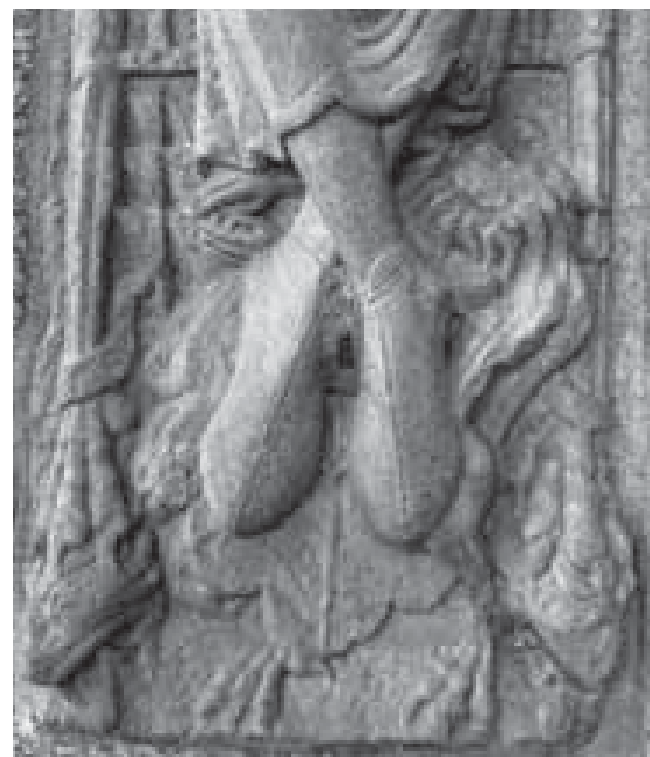

Fig. 17. Detalle del relieve del Rey David procedente de la Porta Francigena (ca. 1105). Portada de Platerías, Catedral de Santiago de Compostela.

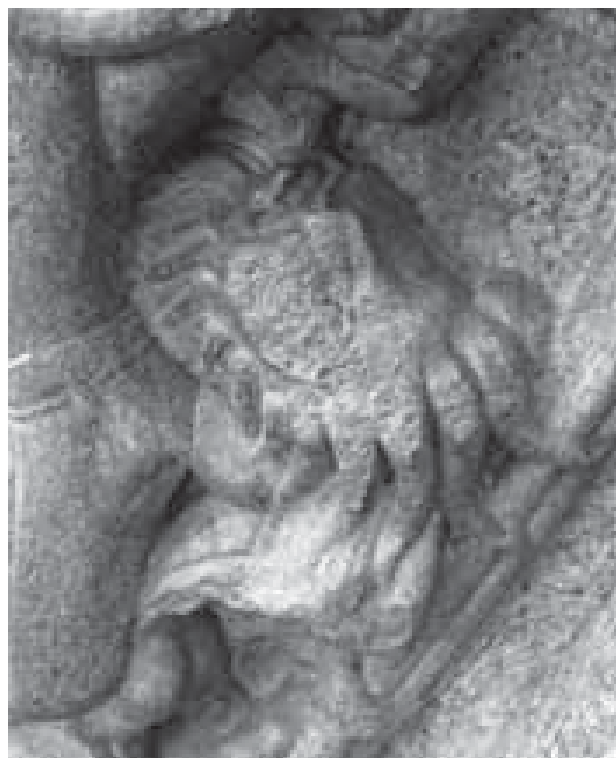

Fig. 18. Detalle del relieve del Rey David procedente de la Porta Francigena (ca. 1105). Portada de Platerías, Catedral de Santiago de Compostela.

Cristo venció a la muerte. Por lo tanto, partiendo de un contraste alegórico entre la música cósmica de salvación entonada por David y la música carnal de muerte entonada por las sirenas, se construía un discurso de carácter cristológico en el que la victoria de Ulises pasando indemne frente a la sirenas atado al mástil de la cruz correspondería a David sometiendo a los demonios con la música celestial producida por su instrumento crucífero. A la vez, ambos episodios, como ocurre con otros de esta portada, enlazarían tipológicamente con acontecimientos de la vida de Cristo representados en Platerías, funcionando como prefiguraciones tanto de la Pasión, representada en el tímpano derecho, como de su victoria sobre las Tentaciones figurada en el tímpano izquierdo. Finalmente, la conexión entre la columna odiseica y la figura del rey David en la Porta Francigena traía a la mente la asociación entre éste y el mar en la tradición jacobea. La carta del papa León IX, principal relato de la traslación del apóstol, nos cuenta que al llegar al puerto de Iria con el cuerpo de Santiago, los discípulos, "en su alegría entonaron este verso de David: Fue el mar tu camino y tu senda la inmensidad de las aguas"62.

Lo aquí expuesto introduce nuevos elementos para enriquecer la acertada caracterización que Castiñeiras realiza de Diego Gelmírez como un "comitente viajero" que logró convertir a Compostela en un "centro de arte de vanguardia" ${ }^{3}$. Ayuda también a redimensionar en su justa medida el modo en el que la supuesta adhesión de

\footnotetext{
62 Liber sancti Iacobi, p. 393.

63 CAStiÑEIRAs, "La Porta Francigena: una encrucijada en el nacimiento del gran portal románico", pp. 89-118.
} 


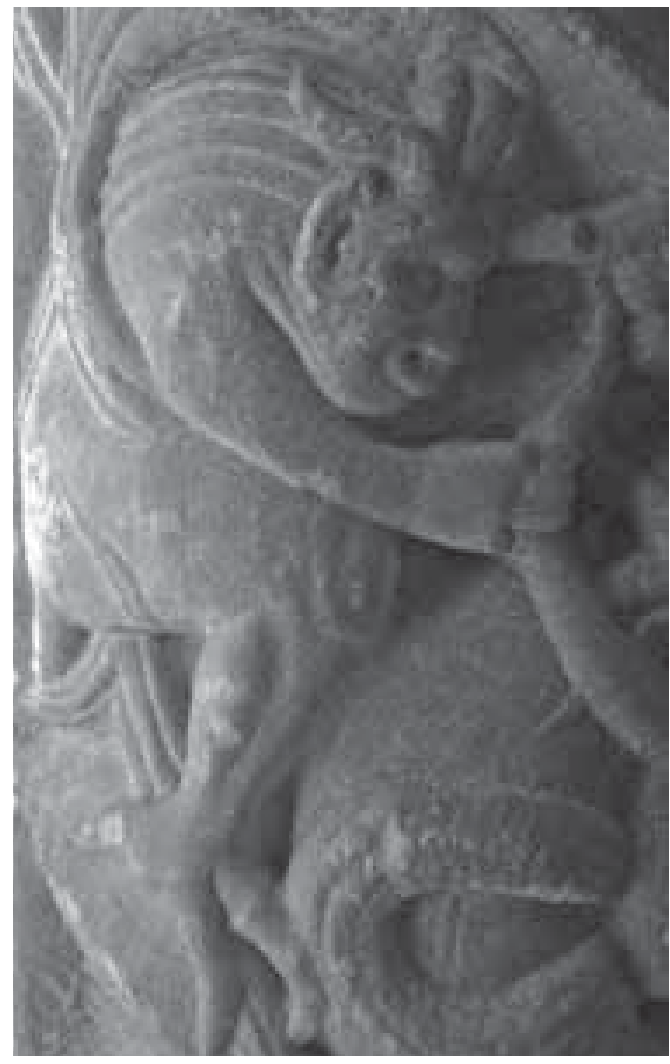

Fig. 19. Detalle de la columna procedente de la Porta Francigena (ca. 1105). Museo de la Catedral de Santiago de Compostela.
Gelmírez a la ideología de la reforma gregoriana constituye, como sugiere Castiñeiras, el principio definidor del programa de la Porta Francigena, donde se buscaría emular a la Roma papal. Siguiendo a Moralejo, quien había visto en la iconografía de las otras columnas marmóreas de esta portada, decoradas con putti vendimiadores, una referencia formal a las columnas salomónicas de la pérgola de San Pedro, e iconográfica a las alegorías de la buena y mala viña desarrolladas en el contexto de la reforma gregoriana, Castiñeiras añade nuevos elementos comparativos incrementando el peso de la deuda del programa de esta portada a un modelo estético-ideológico romano ${ }^{64}$. Sin embargo, la elucidación de la iconografía de la columna de Ulises y de su relación con la estructura cronográfica de la Porta Francigena, que está articulada en torno a la idea fundamental de una humanidad peregrina a Occidente, indica que Gelmírez no estaba meramente emulando el lenguaje visual de la reforma gregoriana sino creando una iconografía sacra y mítica nueva, específicamente compostelana, para la promoción de la centralidad de su sede. Como se deduce de mi análisis comparativo del sesgo ideológico común que presentan la cartografía del mapamundi de Osma y la cronografía de la Porta Francigena, la visión que Gelmírez tenía de la centralidad apostólica de su sede era tan ambiciosa como la que le había costado a sus predecesores Cresconio y Diego Peláez la excomunión y el exilio respectivamente ${ }^{65}$. Sin embargo,

${ }^{64}$ S. Moralejo, "El patronazgo artístico de Diego Gelmírez (1100-1140): su reflejo en la obra e imagen de Santiago", Pistoia e il Cammino de Santiago. Una dimensione europea della Toscana medioevale. Atti del Convegno Internazionale di Studi, Pistoia, 28-30 settembre 1984, Nápoles, 1987, pp. 245-72; M. CASTIÑEIRAS, "Roma e il programma riformatore di Gelmírez nella cattedrale di Santiago", Medievo: immagini e ideologie, $V$ Convegno Internazionale di Studi. Parma, 23-27 settembre 2002, (A. C. Quintavalle, ed.), Parma-Milán, 2005, pp. 211-26; e ID., "La Porta Francigena: una encrucijada en el nacimiento del gran portal románico", op. cit.

65 Para la excomunión de Cresconio, véase A. Isla Frez, "Canónicas y renovación eclesiástica en el siglo XI", Memoria, culto y monarquía hispánica entre los siglos X y XII, pp. 93-128, esp. p. 97-8. Para el contexto histórico-artístico de la deposición de Diego Peláez, véase F. Prado-VILAR, "Saevum facinus: estilo, genealogía y sacrificio en el arte románico español”, Goya, 324 (2008), pp. 173-99. 
a diferencia de ellos, Gelmírez supo atraer a su sede a un grupo de canónigos de formación internacional, como Giraldo, con los que consiguió articular una estrategia diplomática más efectiva, que la Historia Compostelana documenta detalladamente, a la vez que se benefició de una coyuntura más propicia en la que la popularidad de la peregrinación a Santiago, donde estaban implicados los intereses económicos de algunos de los mayores centros religiosos de Francia y España, estaba consolidada, haciendo que las aspiraciones de Compostela ya no pudiesen ser ignoradas.

\section{Il suffirait d'imaginer un flabellum: La fragilidad del conocimiento}

Allí mismo... hay talladas por todo alrededor muchas imágenes de santos, de bestias, de hombres, de ángeles, de mujeres, de flores y de otras criaturas, cuya esencia y calidad no podemos describir a causa de su gran cantidad ${ }^{66}$.

Poco sabemos del autor de la guía del peregrino del Liber sancti Iacobi, pero podemos deducir del contenido de sus escritos y de las limitaciones interpretativas de su mirada, que no tenía la altura intelectual ni el conocimiento del legado clásico y la exégesis cristiana que poseían algunos de los canónigos de la Catedral de Santiago que, con seguridad, habían participado en el diseño de los programas iconográficos de las dos grandes portadas del transepto ${ }^{67}$. Aymerico se esforzaba en comprender una obra de arte que era más inteligente y menos prosaica que él. A pesar de que su discurso nos transmite una obra devaluada, el devenir del tiempo ha querido que se erija en fuente primaria para el monumento, mientras que otras voces más sutiles, inteligentes y relevantes para entender su significado y captar su dimensión histórica y estética nos han llegado en fragmentos, sólo susceptibles de ser rescatadas a través un complejo ejercicio de investigación histórica y de recuperación de la memoria. Giraldo es el representante de una comunidad de intelectuales que se pierde en la nube de olvido pero que es fundamental para el entendimiento de la génesis de esta obra cumbre, y esencialmente compostelana, que es la Catedral de Santiago: su escuela episcopal ${ }^{68}$. Sabemos que un eje primordial del

${ }^{66}$ Liber sancti Iacobi, p. 560.

${ }^{67}$ Para un análisis del valor de la guía del peregrino como fuente histórico-artística: S. MoralEJo, "The Codex Calixtinus as an Art-Historical Source", The Codex Calixtinus and the Shrine of St. James, (J. J. Williams and A. Stones, eds.), Tübingen, Gunter Narr Verlag, 1992, pp. 207-28.

${ }_{68}$ El estudio seminal sobre la escuela episcopal compostelana es M.C. DÍAZ Y DÍAZ, "Problemas de la cultura en los siglos XI-XII: la escuela episcopal de Santiago", Compostellanum, 16 (1971), pp. 187-200; véase también la reciente aportación de RUCQUOI, "De grammaticorum schola...”, op. cit. Quiero expresar aquí mi reconocimiento al deán de la Catedral de Santiago D. José María Díaz y a D. Daniel Lorenzo, con los que he tenido la fortuna de colaborar en el marco de mi función como coordinador del comité científico del programa de restauración del Pórtico de la Gloria. La visión de sus predecesores se ve honrada por los criterios de excelencia con los que están desarrollando su labor en los proyectos de conservación del monumento. 
proyecto de Gelmírez para convertir a Santiago en una sede apostólica de primera línea fue la educación de sus canónigos. La Historia Compostelana nos informa que envió a clérigos a estudiar a Francia y a otros centros de prestigio, a la vez que atrajo a intelectuales como Giraldo de Beauvais para que ejerciesen como magister y didascalus en su escuela episcopal ${ }^{69}$. Esta escuela se encontraba en las inmediaciones de la catedral, muy cerca de la Porta Francigena, por donde Giraldo y sus alumnos, tras haber leído a Virgilio, Ambrosio, Boecio, Isidoro, los mitógrafos, y haber comprobado con deleite y orgullo en un mapamundi como el de Osma que estaban viviendo en el centro del universo, pasarían frecuentemente mientras se diseñaba el gran portal románico, siendo testigos y partícipes de la transformación de figuras de pensamiento en imágenes pétreas.

Habiéndose perdido casi en su totalidad la biblioteca de la escuela episcopal de Santiago, no hubiésemos tenido ningún testimonio textual de la profundidad intelectual de esta comunidad de pensamiento, si Giraldo no hubiese elevado su discurso por encima de la pauta marcada por los otros autores de la Historia Compostelana, dejando traslucir la amplitud de su educación en la articulación de su prosa, rica en pinceladas clásicas de incalculable valor para el entendimiento de obras maestras como la columna de Ulises ${ }^{70}$. Al igual que ocurre con la voz de Giraldo y sus compañeros de la escuela compostelana (Raucelino, Rainiero, Guido), cuya brillantez se registra en las obras que inspiraron como la Porta Francigena, las portadas de la Catedral de Santiago contienen el registro pétreo de otros mundos perdidos que son de esencial importancia para reconstruir el momento cultural en el que se creó la gran obra románica ${ }^{71}$. Se puede decir de la Catedral de Santiago y la comunidad de intelec-

${ }^{69}$ La Historia Compostelana informa que Gelmírez envió a su sobrino Pedro, deán de la iglesia de Santiago, a estudiar a Francia la "disciplina filosófica" (Historia Compostelana, p. 380) y nos habla de otro personaje al que "lo había educado el obispo desde niño en su palacio y le había honrado en la iglesia de Santiago, luego ya de adulto lo había enviado a Francia a aprender la gramática" (Historia Compostelana, p. 280). Véase también López Alsina, La ciudad de Santiago de Compostela en la Edad Media.... op. cit., pp. 65-6; e Isla Frez, "Canónicas y renovación eclesiástica en el siglo XI”, op. cit.

70 Del mismo modo, poco se imaginaba Giraldo que cuando se refería a la reina Urraca como una "fiera Erinia" (Historia Compostelana, p. 397) no sólo estaba pintando de forma efectiva un retrato psicológico del personaje sino que nos estaba dejando el único registro textual de una figura fundamental en el estudio de la pervivencia de lo clásico en el arte de su tiempo, desde el sarcófago de Husillos, pasando por el capitel de Caín de Frómista hasta las imagines feminarum de la Porta Francigena, véase S. Moralejo, "Sobre la formación del estilo escultórico de Frómista y Jaca," Actas del XXIII Congreso Internacional de Historia del Arte, (Granada 1973), vol. 1, Granada, 1976, pp. 427-34; Prado-VILAR, «Saevum facinus...” op. cit., p. 181; ID., "Diario de un argonauta..." op. cit., pp. 103-104; e ID., “Tragedy's Forgotten Beauty...” op. cit., esp. p. 101.

${ }^{71}$ En su apreciación de las cualidades de Giraldo como historiador, Fernández Almuzara realiza una sugerente comparación con la obra de la catedral: "Tenía Giraldo excelentes condiciones de historiador a la manera clásica. Sabe dar unidad orgánica a la narración...; gradúa los efectos; subordina las acciones secundarias a la principal y constituye a su héroe en eje dramático del relato...; como Tácito, poseía el don de la caracterización psicológica... Lástima que no fuera él el encargado de escribir toda la Crónica Compostelana. Porque hubiera tenido una unidad de pensamiento, de método y estilo de que carece, y hubiera sido, dentro de la literatura románica del siglo XII, lo que es el Pórtico de la Gloria en arquitectura," véase E. FERNÁNDEZ AlmuZara, "En torno a la Crónica Compostelana", Escorial, 6. 17 (1942), pp. 341-74, esp. pp. 349-50. 
tuales y artistas que la crearon lo que acertadamente dijo Gonzalo Torrente-Ballester de la literatura: "Para que un libro sea leído y cogido en toda su integridad, que no es solamente lo que está escrito, hace falta que el lector tenga una riqueza empírica, una riqueza de experiencia, tan grande por lo menos como la del autor"72.

La fotografía del viejo profesor de Harvard perdiéndose en la niebla constituye un testimonio elocuente de la fragilidad de la Historia del Arte medieval español como proyecto intelectual, al registrar el carácter efímero de un momento en el que los discursos articulados en torno a nuestros monumentos estaban en la vanguardia de la disciplina. El pulso intelectual y ético de las conversaciones entre los eruditos de aquel período se puede calibrar en un célebre artículo de Porter en el que, planteando la cuestión de la prioridad de Santiago o Toulouse, critica la tendencia nacionalista y homogeneizante de la historiografía francesa, empeñada en retrasar las cronologías de los monumentos hispanos y sobredimensionar el papel Cluny - una tendencia que curiosamente está experimentando un cierto revival tardío a pasar de estar desvinculada por completo de la evidencia arqueológica, estilística y documental. En él encontramos un pasaje donde Porter desarrolla una lectura crítica lúcida y cuidadosa de la obra de E. Mâle donde se contiene un verdadero manifiesto de los estándares a los que debe sujetarse la Historia del Arte moderna:

La unión de la investigación de la más alta calidad con la más delicada presentación escrita ha sido siempre el ideal perseguido por M. Mâle y, en conjunto, ha logrado alcanzarlo con sorprendente éxito. Su trabajo combina la profundidad de pensamiento con la belleza de forma hasta un nivel raramente conseguido hasta la fecha... M. Mâle es un erudito competente, quizá el más competente sobre su tema viviendo en la actualidad. Posee un conocimiento increíblemente extenso, preciso, y profundo. Su mente es a la vez aguda y poética. Incluso cuando uno difiere de sus teorías, no puede por menos que admirar la destreza con que las sustancia; y los argumentos que se extrapolan de su libro, la gran cantidad de ideas que parece lanzar de forma extemporánea con sorprendente facilidad, se cuentan entre las mayores contribuciones que se han hecho a la literatura sobre el arte medieval ${ }^{73}$.

72 Entrevista recogida en el DVD que acompaña a Los mundos de Gonzalo Torrente Ballester, 2 vols. (Madrid: Sociedad Estatal de Conmemoraciones Culturales, 2010). Para Torrente, autor de El retorno de Ulises, al igual que para otros escritores gallegos del s. XX, como Álvaro Cunqueiro, Otero Pedrayo o Vicente Risco, el mito de Ulises figura de forma especial en su producción literaria. Para una reflexión en clave de "poética cultural" sobre la estructura figurativa de la columna de Ulises, su presencia en Santiago y los escritores de la generación Nós, véase Prado-Vilar, "Nostos...” op. cit., pp. 268-69.

73 A. K. Porter, "Spain or Toulouse? and Other Questions", Art Bulletin 7.1 (1924), pp. 3-25, esp. p. 3. Dos años más tarde, en otro artículo seminal para la difusión de la historiografía y el arte medieval españoles en América, Porter publicó uno de los semblantes más memorables que se hayan escrito sobre Gómez-Moreno, comparándolo con el Klingsor del Parsifal de Wagner: "Su nombre [Gómez-Moreno] se convirtió en una especie de mito en el mundo del conocimiento -se susurraban las historias más extrañas sobre su erudición, sobre lo que se contenía en su colección de fotografías, que nadie había visto nunca, de lo que podía contar si quisiese... Se convirtió en una especie de mago, una figura variopinta como la de ningún otro erudito en esta era prosaica, poseyendo algo misteriosamente oriental e impenetrable, sobrehumano, como un Klingsor. Y cuanto menos escribía, cuanto menos se le veía, más se sentía su influencia invisible en el pensamiento arqueológico de dos continentes. Luego llegó la publicación de Iglesias mozárabes, que al instante pasó a ocupar su lugar entre los clásicos de la arqueología", véase A. K PORTER, "Leonesque Romanesque and Southern France", Art Bulletin 


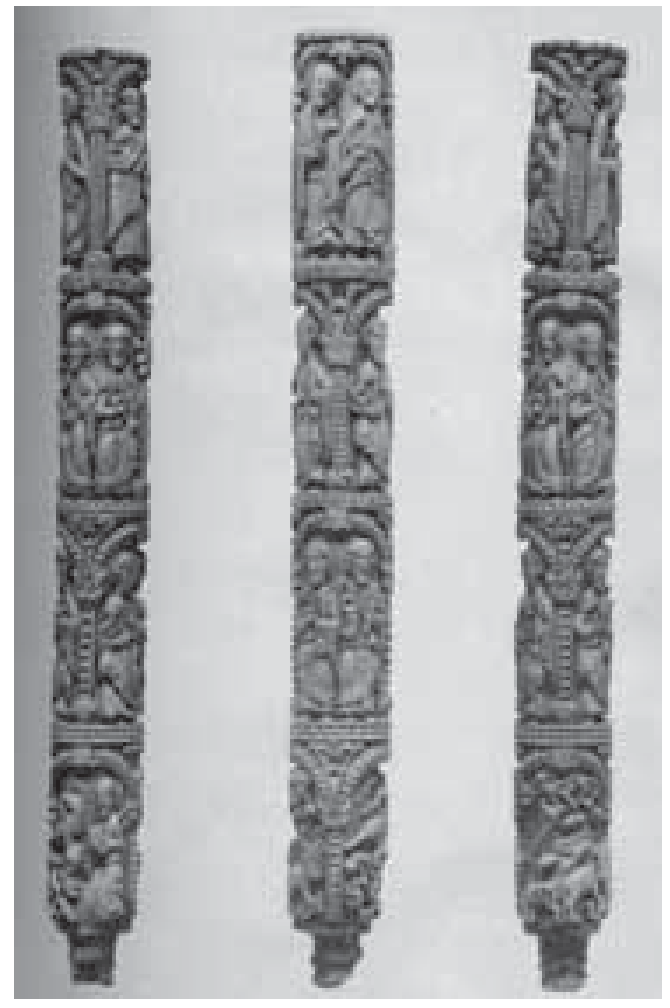

Fig. 20. Mangos de flabellum. Londres, British Museum: Foto: A. Goldschmidt Die Elfenbeinskulpturen aus der Romanischen Zeit. XI. - XIII. Jahrhundert, Berlin 1926. fig. 66
Cuando eso sucede, como es el caso de la obra del propio A. Kingsley Porter, M. Gómez-Moreno, M. Schapiro o S. Moralejo, incluso las intuiciones más sucintamente esbozadas pueden permanecer latentes en los márgenes de sus escritos esperando a ser retomadas por generaciones posteriores. Mirando a las columnas marmóreas de la fachada de Platerías, Moralejo intuyó la influencia de las artes suntuarias y dejó registrada su observación en la nota 13 del magistral artículo en el que reconstruye el mobiliario litúrgico de catedral, otro de esos pilares perdidos, como ocurre con la biblioteca episcopal, del programa de engrandecimiento de Gelmírez en Compostela: "It suffirait d'imaginer un flabellum comme celui que repère A. Goldschmidt au British Museum, dans un style comme celui des plaques de la châsse de San Felices ${ }^{74 "}$. Retomando esta observación con gran sagacidad, Charles Little ha conseguido restituir a su correcto contexto estilístico en los talleres del Camino de Santiago un grupo de objetos de marfil de extraordinaria calidad e interés iconográfico que hasta ahora yacían desprovistos de una marco histórico definido: los mangos de flabellum del British Museum mencionados por Moralejo (fig. 20), y los báculos episcopales en tau del Metropolitan Museum de

8.4 (1926), pp. 235-50, esp. p. 235. Poco después, M. Schapiro, sin duda alentado por Porter, aprovechó su paso por Madrid para visitar a Gómez-Moreno. En una carta fechada en el 1 de agosto de 1927, relata a Lillian la experiencia de este encuentro con similar apreciación: "Vengo de ver a Gómez-Moreno, quien fue sumamente afable y tranquilo y me dio más en una hora que lo que había encontrado en semanas de viaje y estudio. Fue poca información pero toda sorprendente y original. Me asombró su libertad. Otros se han mostrado reservados y desconfiados ante mis preguntas. Él estaba siempre sonriendo y con actitud divertida ante sus propios descubrimientos. Parece el padre perfecto y a la vez, curiosamente, es como ese moro sensual e indolente de los libros ilustrados y las historias... Quizá vuelva a verle en Santiago”, véase Meyer Schapiro Abroad..., op. cit., p. 101.

74 S. Moralejo, "Ars Sacra et sculpture romane monumentale: le trésor et le chantier de Compostelle", Les cahiers de Saint-Michel de Cuxa, 2 (1980), pp. 189-238, esp. n. 13. Para los dibujos que de estas columnas hizo M. Schapiro durante su estancia en Santiago en agosto de 1927, véase Meyer Schapiro Abroad..., op. cit., pp. 179-180. 
Nueva York y del Museo Nazionale del Bargello en Florencia ${ }^{75}$. Podríamos decir que, al igual que el fuste marmóreo de la Isla del Solsticio del relato de Trezenzonio, en el que se registraban las coordenadas principales del mundo que lo albergaba, las columnas de mármol de las portadas de la Catedral del Santiago contienen el registro pétreo de los productos efímeros de ese excepcional momento cultural en el que se erigió el templo románico: la brillantez intelectual de la escuela episcopal (columnas de la Porta Francigena) y el esplendor artístico del mobiliario litúrgico (columnas de Platerías) ${ }^{76}$.

El tropo del flabellum es útil para explorar los significados codificados en la dimensión fenomenológica de la apreciación de los programas escultóricos de las dos portadas del transepto. Mirando a las columnas entorchadas de la Porta Franci-

75 CH. Little, “Along the Pilgrimage Road: Ivories and the Role of Compostela", Patrimonio artístico de Galicia y otros estudios. Homenaje al Prof. Dr. Serafin Moralejo, vol. III, (A. Franco MatA, ed.), Santiago, Xunta de Galicia, 2004, pp. 159-66. La presencia de flabella en la Catedral de Santiago está documentada desde la donación de Ordoño II, véase J. Filgueira Valverde, El tesoro de la Catedral compostelana, Santiago de Compostela, Bibliófilos Gallegos, 1959, pp. 6-10.

76 Otro objeto perdido del tesoro compostelano que merecería tratamiento dentro de un estudio más amplio sobre el imaginario clásico presente en la Catedral de Santiago es la Cruz de Alfonso III, desaparecida en 1906, y conocida por reproducciones y descripciones de sus camafeos, véase A. Blanco Freijeiro y J. Filgueira Valverde, "Camafeos y entalles del Tesoro Compostelano", Cuadernos de Estudios Gallegos, 13 (1958), pp. 137-145. Para una discusión del camafeo de Eneas de la Cruz de los Ángeles en el marco de un análisis de las imágenes meta-textuales de la Historia Seminense y la ideología de los programas iconográficos de San Isidoro de León, véase PRADO-VILAR, "Lacrimae rerum...", op. cit., pp. 197-99. En la nota 13 de "Lacrimae rerum" propongo una asociación entre el rostro del camafeo del cáliz de Urraca y el nombre de la infanta con el que está axialmente conectado. En su contribución a las IV Jornadas Complutenses de Arte Medieval de la que derivan estas actas, T. Martin descartaba la posibilidad de esta asociación basándose en argumentos iconográficos comparativos (ausencia de velo y exposición del cabello) extrapolados de retratos de la infanta como deo vota en miniatura. Tal argumento obvia la diferencia de medio, tradición y conceptualización retórica en los que se enmarca la creación de este camafeo, que nada tiene que ver con los ejemplos esgrimidos sino que se trata de un retrato ad antiquum siguiendo deliberadamente modelos clásicos, frecuentemente reutilizados en las artes suntuarias, para dotarlo de una pátina romana. De hecho, en vez de constituir un signo de falta de decoro, la disposición del pelo en el retrato del camafeo, cuidadosamente recogido en bucles sobre la frente, indica una idea de decoro femenino presente en camafeos clásicos y adoptado en otros ejemplos de la plástica contemporánea como la mujer del signum leonis del relieve de Saint-Sernin de Toulouse (para esta obra, véase la ficha de catálogo, con bibliografia previa, en Compostela y Europa, pp. 314-19, la cabeza del camafeo esta cortada exactamente en el área que correspondería al borde del velo en la escultura tolosana). Finalmente, Martin no articulaba entonces una teoría alternativa convincente que explicara el posible significado de la colocación ostentosa de un camafeo de rostro creado ex novo (y no reutilizado) en relación al nombre de la comitente, asignando su presencia a un indefinido "gusto por la antigüedad" (dentro de este análisis, el significado sería el mismo si en vez de tratarse de un rostro frontal, se tratase de un busto imperial laureado, un sátiro o un ciervo). Argumentos reduccionistas de esta naturaleza, donde se engloban obras tan diversas conceptual y contextualmente como una cruz otoniana, una relicario capeto o el cáliz de Urraca, podrían evitarse considerando la extensa bibliografía sobre el tema publicada en los últimos veinte años donde se ha explorado la polivalencia de significados que tendrían en la Edad Media los variados modos de reutilización, cita y copia de lo clásico en las artes suntuarias, así como las importantes cuestiones teóricas que éstos suscitan. Para un estado de la cuestión de estos debates, con bibliografia actualizada, véase D. KenNEY, "The Concept of Spolia", A Companion to Medieval Art. Romanesque and Gothic in Northern Europe, (C. RudolPH, ed.), Londres, Wiley-Blackwell, 2010, pp. 232-53; y, especialmente, A. CuTLER, "Reuse or Use? Theoretical and Practical Attitudes Towards Objects in the Early Middle Ages", Ideologie e pratiche del reimpiego nell' altro medievo. 16-21 aprile 1998, 2 vols., Espoleto, 1999, vol. 2, pp. 1055-83; e I. H. ForSYTH, "Art with History: The Role of Spolia in the Cumulative Work of Art", Byzantine East, Latin West. Art Historical Studies in Honor of Kurt Weitzman, (CH. Moss y K. KeIFER, eds.), Princeton, Princeton University Press,1995, pp. 153-62. 
gena, recorridas por formas en continua transformación y metamorfosis, podemos imaginarnos un flabellum en movimiento en el que las imágenes grabadas en el mango se dinamizan desplazándose en el espacio, a la vez que adquieren una temporalidad narrativa sincopada por sus apariciones y desapariciones en el campo de visión, participando de ese modo en el sentido de "revelación" que se dramatiza en la escenografía litúrgica en la que se enmarcan ${ }^{77}$. En contraste, al observar las columnas marmóreas de la Portada de Platerías, cuyos relieves se articulan en espacios compartimentalizados donde las figuras aparecen frontales y estáticas en una retícula vertical, nos imaginamos un flabellum en reposo. Esta magistral división estilística hacía que el espectador, en su peripateia visual por la Porta Francige$n a$, "sintiese" el movimiento de una humanidad peregrina que, tras el pecado y la expulsión del Paraíso, se había visto abocada a la incierta travesía a través de los peligros del saeculum, un mundo sujeto a la temporalidad y al capricho de una naturaleza previsible, representada por el ciclo los meses, y a la vez incontrolada, con la presencia de personajes híbridos como sirenas y centauros representantes de las pasiones y el pecado. Luego, tras recorrer esa otra recapitulación topográfica del peregrinaje que es la secuencia de capillas del deambulatorio dedicadas a advocaciones relativas a santuarios del camino, y rezar ante la tumba del apóstol, el peregrino llegaba a la Portada de Platerías donde podía apreciar la estabilidad de la arquitectura de la iglesia de Cristo en la tierra, sustentada por las columnas con los retratos de los apóstoles y las jerarquías eclesiásticas, que servía de telón de fondo para el ritual de la restauración del orden en la sociedad por medio de los juicios presididos por sus vicarios en la tierra ${ }^{78}$. Nada es comparable en el arte de su tiempo. La tan manida cuestión Santiago-Toulouse resulta irrelevante en los términos en los que ha sido planteada, ante la abismal diferencia conceptual y cualitativa entre los dos polos de la ecuación. Saint-Sernin continúa siendo un monumento extraordinario, pero Santiago juega en otra liga ${ }^{79}$.

\footnotetext{
77 Para un extraordinario estudio sobre la percepción de las imágenes grabadas en el flabellum carolingio de Tournus, véase H. L. Kessler, "Images Borne on a Breeze: the Function of the Flabellum of Tournus as Meaning", trabajo inédito presentado en el simposio, Light, surface, spirit: phenomenology and aesthetics in Byzantine art, Dumbarton Oaks (Washington DC), Noviembre 2009. Agradezco al autor por haber compartido conmigo el manuscrito de este trabajo. Para los relieves que ilustran églogas de Virgilio en el flabellum de Tournus, véase J. M. Ziolkowski y M. C. J. Putnam, eds., The Virgilian Tradition. The First Fifteen hundred Years, New Haven, Yale University Press, 2008, pp. 436-8. Para una discusión general de la función y simbolismo del flabellum como objeto litúrgico, véase H. Richardson, "Remarks on the Liturgical Fan, Flabellum or Rhipidion", The Age of Migrating Ideas: Early Medieval Art in Northern England and Ireland, (R. M. Spearman y J. Higgitt), Edimburgo, Alan Sutton Publishing, 1993, pp. 27-34.

78 Sobre la administración de justicia en Platerías, véase M. CASTIÑEIRAS, «Platerías: Función y decoración de un 'Lugar Sagrado»', Actas del V Congreso Internacional de Estudios Jacobeos, Santiago de Compostela, 2000, pp. 289-331, esp. pp. 321-31.

79 Sobre Saint-Sernin de Toulouse: D. CAZES y Q. CAZES, Saint-Sernin de Toulouse. De Saturnin au chef d'oeuvre de l'art roman, Toulouse, 2008. Para un análisis de los factores que contribuyeron al desplazamiento a los márgenes del canon del románico de una obra maestra de la escuela hispano-languedociana, el capitel del sátiro de Jaca, en favor de obras situadas en los centros geopolíticos en torno a los que este se formó, véase PRADO-VILAR, "Diario de un argonauta..." op. cit., pp. 95-107.
} 
La imagen del flabellum es también apropiada en el marco de la reflexión historiográfica articulada en este estudio. Inscrito en el hermoso flabellum de Tournus se encuentra un epígrafe que enuncia su función en la preservación del cuerpo eucarístico: "ad refrigerandum aerem [et] ad abigendas muscas" (para refrescar el aire y espantar a las moscas) - una sugerente figura para meditar sobre la responsabilidad de las nuevas generaciones de historiadores del arte ante el corpus intelectual del que somos herederos. Se trata de un corpus de pensamiento delicado y brillante cuya preservación y engrandecimiento requiere realizar el esfuerzo necesario para estar a la altura del talento, la dedicación y "la riqueza empírica" de los autores que lo crearon, cuyo legado se ve oscurecido de forma recurrente en períodos en los que prevalece la autocomplacencia y la laxitud de estándares académicos sobre la solidez metodológica, la excelencia intelectual y la "energía dialéctica" que son indispensables para evitar caer en el revisionismo fácil y producir un verdadero movimiento de innovación en la disciplina ${ }^{80}$. Retomando las palabras con las que la Historia Compostelana describe la labor de Diego Gelmírez, se podría decir que esa responsabilidad pasa primero por asumir la tarea de "restaurar lo destruido, conservar lo restaurado y conducir lo conservado, no sin mucho trabajo, a estado de perfección"

En los depósitos de la Fundación Juan March de Madrid se esconde un hito inédito de la historiografía española, la memoria de un joven historiador del arte llamado Serafín Moralejo, donde se exploran a la perfección las preguntas que Porter se estaba formulando en el momento de su desaparición ${ }^{82}$. Con impecable prosa y un aparato crítico a la altura de los más exigentes estándares internacionales de la época, Moralejo nos dejó mecanografiada la memoria de los hallazgos realizados en ese annus mirabilis en el que sentó las bases de algunas de las líneas de investigación más productivas para el estudio de arte románico español. En la conclusión de su estudio y del volumen de fotografías que lo acompaña, el autor esboza una comparación intuitiva entre el relieve de San Pelayo de la Portada de Cordero de San Isidoro de León y la delicada estatua que representa a Hispania cautiva en el monumento triunfal dedicado en Saint-Bertand-de-Comminges (Lugdunum convenarum) en el año 25 a. C. para conmemorar las victorias de Augusto a ambos lados

${ }^{80}$ Utilizo la expresión "energía dialéctica" en el sentido que Gombrich dio a la palabra Auseinandersetzungsenergie, acuñada por Warburg en la ultima versión de su famosa conferencia sobre los frescos del palacio Schifanoia de Ferrara, para referirse a la capacidad innovadora de artistas e intelectuales como Picasso y Warburg, véase E. GoмвRich, "Aby Warburg: His aims and methods - an anniversary lecture", Journal of the Warburg and Courtauld Institutes, 62 (1999), pp. 268-82, esp. p. 276-80.

${ }^{81}$ Historia Compostelana, p. 80.

82 Agradezco a Dulce Ocón por haberme informado sobre la existencia de este documento. En el tiempo transcurrido desde la finalización de este artículo y la revisión de las pruebas de imprenta, se ha producido la muerte de Serafín Moralejo, a quien dediqué una semblanza en la prensa que puede servir de coda a las reflexiones aquí realizadas: "Serafín Moralejo: la poética del humanismo" suplemento Culturas de La Voz de Galicia, 17 de septiembre de 2011, y que se reproduce al comienzo de este volumen. Durante el mismo período se produjo otro suceso, la desaparición del Códice Calixtino del archivo de la Catedral de Santiago, que enlaza con las meditaciones en torno a la fragilidad del registro arqueológico y documental desarrolladas en estas páginas, y sobre el que también tuve ocasión de publicar un artículo relatando las circunstancias de la última vez que lo examiné: "El Aura del Códice", suplemento Culturas de La Voz de Galicia, 6 de agosto de 2011. 
de los Pirineos (fig. 21) ${ }^{83}$. Si la fotografía de Porter en la playa de Inishbofin constituía un evocador epílogo a su carrera, este díptico se erige en un digno prólogo para la trayectoria intelectual del historiador del arte gallego, en la que habría de delinear de forma magistral los caminos a seguir para comprender la belleza de esa España medieval cautivada por el legado clásico.

Mientras que Giraldo invocaba a Escila y Caribdis para transmitir a la posteridad la memoria de los peligros a los que su patrón y él mismo se habían enfrentado en

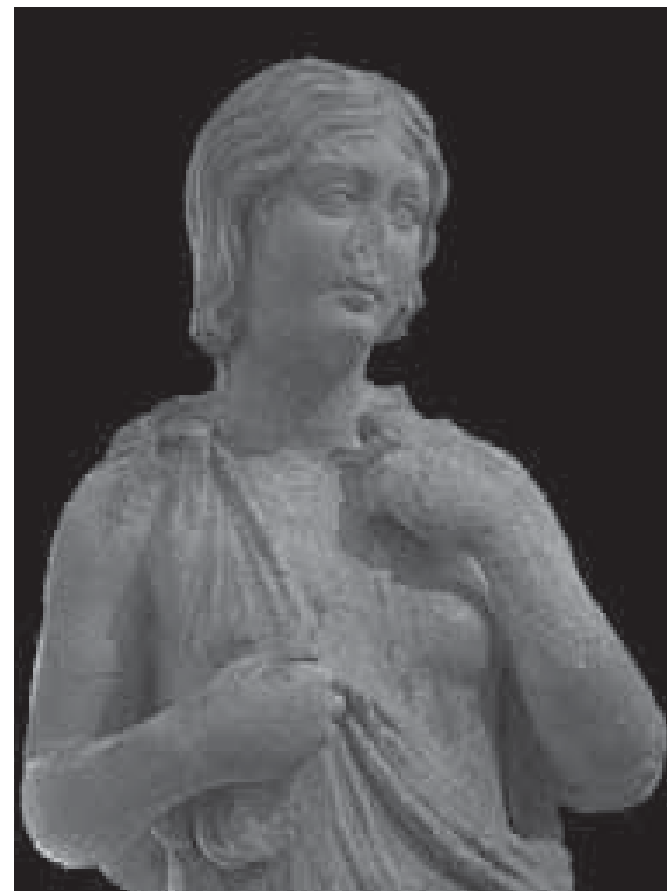

Fig. 21. Hispania cautiva del Trofeo de Augusto (ca. 25 a. C.). Saint-Bertrand-de-Comminges, Musée archéologique départemental. pos de la grandeza de su sede, uno de los intelectuales más brillantes de su tiempo recurría a las mismas imágenes para escribir su Confessio fidei Universalis. Templando su indignación ante la mendacidad de sus adversarios, Pedro Abelardo eleva su voz sobre la cacofonía de los que habían intentado ahogarla, dejándonos uno de los documentos más hermosos, íntimos y memorables del corpus de la literatura medieval una composición rítmica y sonora cuya estructura gramatical encuentra su parangón visual en la concatenación de imágenes de la columna marmórea compostelana:

Haec itaque est fides in qua sedeo, ex qua spei contraho firmitatem. In hac locatus salubriter, latratus Scyllae non timeo, vertiginem Charybdis rideo, mortiferos Sirenarum modulos non horresco. Si irruat turbo, non quatior. Si venti perflent, non moveor. Fundatus enim sum supra firmam petram $^{84}$.

83 Para este monumento, véase S. Silberberg-Peirce, "The Many Faces of the Pax Augusta: Images of War and Peace in Rome and Gallia Narbonensis", Art History 9.5 (1986), pp. 306-24; S. EscONDE-CLEARY, Rome in the Pyrenees: Lugdunum and the Covenae from the first century B.C. to the seventh century A.D., Londres, Routledge, 2007, pp. 31-4; G. Ch. PICARD, Les trophées romains. Contribution á l'histoire de la Religion et de l'Art triomphal de Rome, Paris, 1959, pp. 257-9 y 273; y E. BouBE, Le Trophée augustéen, Saint-Betrand-de-Comminges, 1996.

84 "Esta es, pues, la fe en que descanso, de la que saco mi fuerza en la esperanza. Anclado en ella con seguridad, no temo el ladrido de Scylla, me río de la ramera Caribdis, y no me atemorizan los horribles cantos de muerte de las Sirenas. La tormenta puede rugir, pero permanezco firme; aunque los vientos soplen, no me mueven. Pues la roca de mi fundamento se mantiene sólida": "Confesión de fe de Abelardo", en Cartas de Abelardo y Eloisa, Madrid Alianza, 1993, pp. 299-301, esp. p. 301. 